\title{
Catalogue of the vascular epiphytic flora of Uruguay
}

\author{
Patricia Mai $^{1 *}$ (1), Andrés Rossado ${ }^{2}$ (1) , José Mauricio Bonifacino ${ }^{2,3}$ (1) and Jorge Luiz Waechter ${ }^{4}$ (if
}

Received: February 21, 2019

Accepted: June 17, 2019

\begin{abstract}
We provide an updated list of the vascular epiphytic flora occurring in native environments of Uruguay based on literature review, herbarium specimens, and fieldwork throughout the country. The catalogue provides standardized information for each species, including accepted name, synonyms used within Uruguay, epiphytic category, distribution within the country, habitat, conservation status, observations, and a voucher citation. The effort documented 73 species for the epiphytic flora of Uruguay ( $3 \%$ of the flora), distributed among 29 genera and 12 families. Bromeliaceae was the richest family (17), followed by Polypodiaceae (16) and Orchidaceae (12). Tillandsia stood out as the most speciose genus with 15 species. Characteristic holoepiphytes was the most diverse ecological category. More than half of the epiphytic species documented for Uruguay (53\%) reach their southernmost geographic distribution in the country, whereas only two mostly epipetric species of Tillandsia - T. arequitae and T. uruguayensis - are endemic to the country. Almost half of the epiphytic species found are presently under categories of threat of extinction, with $60 \%$ of them occurring in national protected areas. Both the richest epiphytic families and the predominance of characteristic holoepiphytes coincide with findings from floristic and ecological studies previously carried out in humid subtropical regions.
\end{abstract}

Keywords: conservation status, epiphytic category, geographic distribution, hemiepiphytes, holoepiphytes, subtropical forests, Uruguay, vascular epiphytes

\section{Introduction}

Epiphytes are plants that germinate and grow on other plants, phorophytes, where they survive without absorbing nutrients from the host plant and without being connected to the ground, at least during some stage of the life cycle (Mirbel 1815; Madison 1977; Benzing 1990). As epiphytes are sustained entirely by nutrients and water available in the canopy (Moffett 2000), parasitic and hemiparasitic plants are not included in this life-form (Benzing 1987), since they extract nutrients and water from the living tissues of the host plant (Moffett 2000).
The most recent estimation of vascular epiphytes in the world reports 27,614 species, distributed in 73 families and 913 genera. The number of species represents ca. $10 \%$ of the diversity of vascular plants of the planet (Zotz 2013a). Vascular epiphytes occur widely across the whole spectrum of phylogenetic diversity, so that epiphytism represents a life-form with multiple independent origins (Gentry $\&$ Dodson 1987). Epiphytes are well-represented within lycophytes and ferns, and are especially numerous among angiosperms. In the latter, the largest diversity occurs in monocots, accounting for approximately $80 \%$ of all epiphytic species, with a high concentration in Orchidaceae and Bromeliaceae (Zotz 2013a). Epiphytic eudicots are

1 Departamento de Ecología y Gestión Ambiental, Centro Universitario Regional del Este, Universidad de la República, 20000, Maldonado, Uruguay 2 Laboratorio de Sistemática de Plantas Vasculares, Facultad de Ciencias, Universidad de la República, 11400, Montevideo, Uruguay

3 Laboratorio de Botánica, Departamento de Biología Vegetal, Facultad de Agronomía, 12900, Montevideo, Uruguay

4 Departamento de Botânica, Universidade Federal do Rio Grande do Sul, 91501-970, Porto Alegre, RS, Brazil

* Corresponding author: patimaimo@gmail.com 
otherwise much less diversified, but occur in a larger number of families, such as the Cactaceae, Ericaceae and Gesneriaceae. Among all epiphytic families, Orchidaceae stands out with more than 18,800 species, representing $68 \%$ of the total of epiphyte flora (Zotz 2013a). This remarkable diversity places the orchids as the most successful plant lineage in canopy colonization (Benzing 1990). This family is only distantly followed by Bromeliaceae with 1,770 species, and Polypodiaceae with 1,252 species, the second and third epiphytic families in species number (Zotz 2013a).

The epiphytic life-form has been reported as a characteristic component of wet and moist forests in tropical regions (Kreft et al. 2004; Kersten 2010; Menini Neto et al. 2016). Several authors documented the contribution of epiphytes to species richness, biological diversity maintenance, primary production and structure of these ecosystems (Gentry \& Dodson 1987; Benzing 1990; Kersten 2010; Freitas et al. 2016). Despite being a typical component of tropical wet forests, vascular epiphytes also occur in subtropical moist forests (Waechter 1998; Rogalski \& Zanin 2003; Giongo \& Waechter 2004; Machado et al. 2016) and to a lesser extent in temperate moist forests (Zotz 2005; San Martín et al. 2008; Pincheira-Ulbrich 2011). Additionally, some species could even be found in arid and semi-arid environments (Gentry \& Dodson 1987).

Uruguay is classified as a subtropical country mostly covered with grasslands, and thus is expected to have a relatively poor vascular epiphytic flora. However, several distinct forest types occur in this country, varying from moist forests along riversides to dry inland thorn forests (Alonso-Paz \& Bassagoda 2002). A relatively high abundance and diversity of epiphytes are considered to be a defining feature for at least one particular forest type, the moist-hillside forest (Alonso-Paz \& Bassagoda 2002; Brussa \& Grela 2007). Nevertheless, there are no studies concerning the entire epiphytic flora of Uruguay and the relationships of this flora with forest types. Most of the present knowledge on vascular epiphytes is addressed in taxonomic studies of families or groups containing epiphytic species, such as ferns (Osten \& Herter 1925; Herter 1928; 1939; 1949; Legrand \& Lombardo 1958; Marchesi 1964; 1979; Mai 2014), peperomias (Trelease [1939]1941; Trelease \& Herter 1952; Marchesi 1968; Mai et al. 2016), orchids (Izaguirre 1972; 1985; 2013; Rossado et al. 2014), bromeliads (Smith 1933; 1972; Marchesi 1965; Smith \& Downs 1977; Brito \& Llano 2008; Rossado 2018; Rossado et al. 2018a; b; 2019), tradescantia (Pellegrini 2018), ficus (Herter 1940; Brussa \& Grela 2007) and cacti (Herter 1930; Lombardo 1946; 1964; Eggli et al. 2008; Berazategui et al. 2010).

The main objective of this study is to provide a complete and up to date list of the vascular epiphytic flora occurring in Uruguay in the form of a catalogue containing additional information on ecological category, eco-geographical distribution, and conservation status for each species.

\section{Materials and methods}

\author{
Study area
}

Uruguay is typical subtropical country, extending between $30^{\circ}-35^{\circ} \mathrm{S}$ and $53^{\circ}-58^{\circ} \mathrm{W}$ (Fig. 1). Climate is humid and warm-temperate, with high air humidity throughout the year and hot summers, corresponding to the Cfa type according to the Köppen-Geiger classification system (Kottek et al. 2006). The mean annual temperature is approximately $17.7^{\circ} \mathrm{C}$, with values decreasing from northwest to southeast of the country; the mean annual precipitation varies from $1200 \mathrm{~mm}$ in the southwest to $1600 \mathrm{~mm}$ in the northeast (Castaño et al. 2011).

Grasslands are the predominant vegetation type in Uruguay and they occupy approximately $70 \%$ of the territory (Puerto 1987), while forests only cover approx. $5.2 \%$, occurring especially along floodplains of rivers and streams, hillsides, and ravines (MGAP 2018). Native forests are classified by the local conditions where they occur or by the dominant tree species. In this sense, based on Alonso-Paz \& Bassagoda (2002) and Brussa \& Grela (2007), we considered the following seven forest types: 1) Butia palm forest (palmar), an open forest or a wooded savanna where the tree layer is dominated by the palms Butia odorata (Barb. Rodr.) Noblick or Butia yatay (Mart.) Becc.; 2) hydrophilous forest (bosque hidrófilo) occurs in temporarily or permanently flooded areas; 3 ) open thorn forest (bosque parque) develops in flat plains of western Uruguay, as a type of wooded savanna dominated by xeric species as Aspidosperma quebracho-blanco Schltdl., Prosopis affinis Spreng., Prosopis nigra (Griseb.) Hieron. and Vachellia caven (Molina) Seigler \& Ebinger; 4) psammophilous forest (bosque psamófilo) occurs on sandy soils, between dunes in wind protected areas along the coast; 5) riverside forest (bosque ribereño) occurs on floodplains of rivers; 6 ) xeric hillside forest (bosque serrano) occurs on dry, stony and shallow soils of hill slopes; 7) moist hillside forest (bosque serrano húmedo) also occurs on hill slopes, steep slopes, sheltered ravines or deep and narrow valleys, where high air moisture and more stable temperatures allow the development of relatively species-rich forests.

\section{Data collection}

The first step in preparing this catalogue was the compilation of a list of species cited in published literature and herbarium specimens deposited at MVFA, MVFQ, MVHC, MVJB and MVM. In addition, specimens of bromeliads and peperomias from Uruguay deposited at BA, CTES, LP and SI were included (herbaria acronyms follow Thiers 2018). This preliminary list was checked, edited and enlarged with the information collected in the field.

Extensive fieldwork was carried out as the second step for this study. Field excursions were planned based on 
the analysis of collection sites given on the herbarium specimens. All the specimens were geo-referenced and mapped, allowing the detection of those regions in the country with no or a low number of collections. Fieldwork was then focused on these regions and carried out from September 2012 to December 2017, including 149 localities throughout all the 19 departments of Uruguay (Fig. 1). In the selected sites, a combination of ground-based techniques (direct observation, binoculars) and climbing methods (Flores-Palacios \& García-Franco 2001) were used to assess the occurrence of epiphytic species. Specimens from all epiphytic species observed at each site were collected and deposited at MVJB or MVFA; whenever needed, sterile live collections were cultivated until flowering for identification purposes. Taxa were identified by studying species types and protologues, by the use of keys and descriptions in taxonomic literature and by the revision of herbarium specimens previously identified by specialists.

\section{Catalogue data}

The systematic classification adopted follows APG (Stevens 2017) for angiosperms and Smith et al. (2006) as modified by Christenhusz et al. (2011) for ferns. Species were named according to the website Flora do Brasil 2020 (2019). The catalogue includes all the species confirmed during fieldwork and with herbarium specimens stating the epiphytic habit and their occurrence in natural forests. In order to assess only epiphytic species naturally distributed in the country, species from urban environments were not included. For each confirmed species the following information was included: accepted name, synonyms previously used in publications of Uruguay, epiphytic category, distribution, habitat, conservation status, nomenclatural comments, observations, and a voucher specimen. For each species the specimen selected as a voucher corresponds with the oldest and most complete

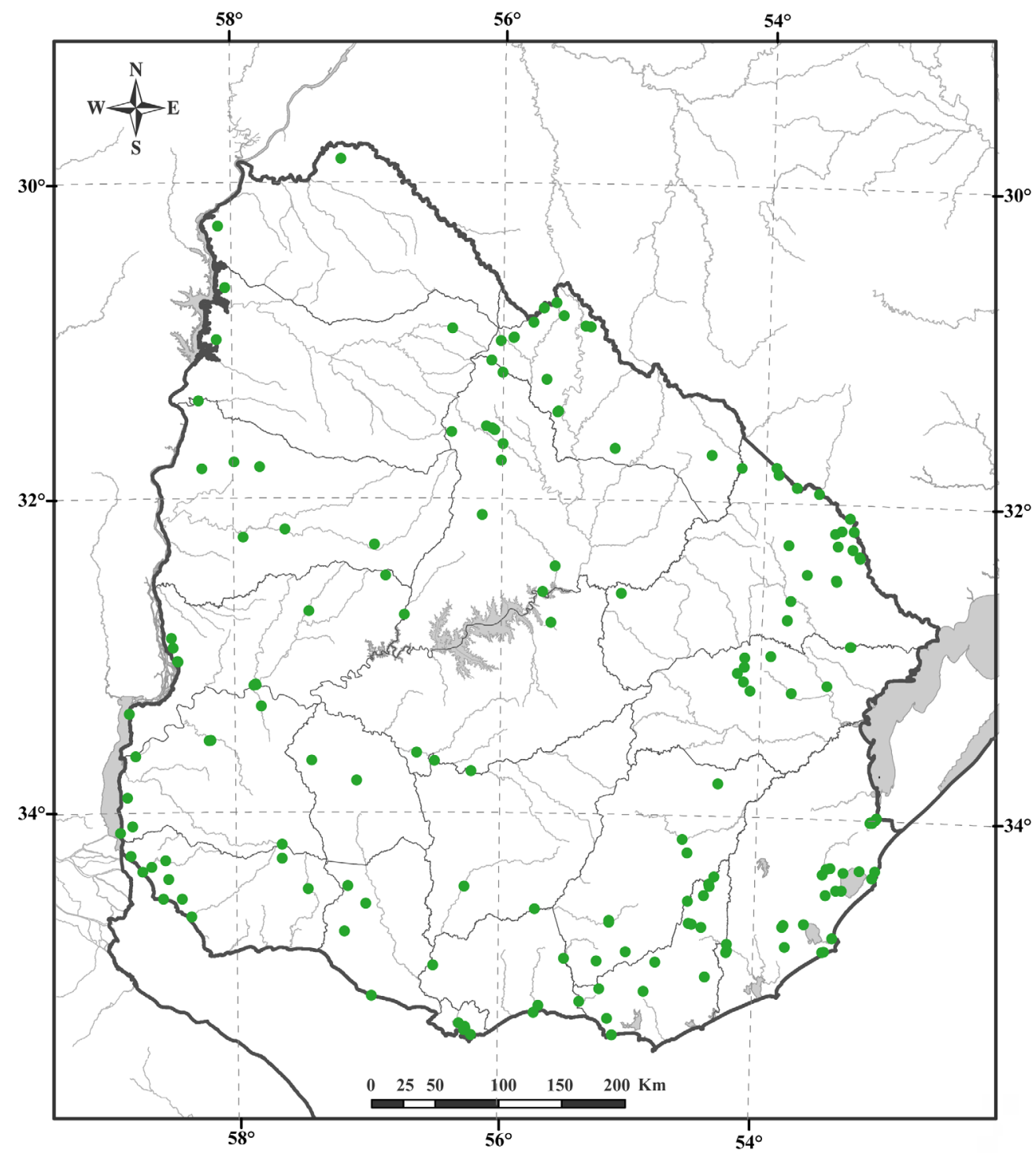

Figure 1. Distribution of sampled localities during fieldwork carried out in Uruguay (green dots). 
specimen with epiphytic habit recorded in national herbaria.

The epiphytic category was assigned according to the relationship with the phorophyte, based on observations carried out during fieldwork. The adaptive classification follows several authors (Benzing 1990; Moffett 2000; Kersten 2010) and distinguishes two main categories: I) holoepiphytes (HL) (permanent epiphytes): species that develop their whole life cycle on the phorophyte, and II) hemiepiphytes (HE) (temporary epiphytes) plants that spend part of their life as epiphytes and another part in contact with the ground. According with Moffett (2000) and Zotz (2013b) (who coined Schimper's (1903) terminology), we considered as $\mathrm{HE}$ only the species which germinate in tree crowns and later establish contact with the ground via aerial roots. The HL category was subdivided into: i) characteristic holoepiphytes (HLC) (obligate, true or habitual): species that always germinate, grow and reproduce in the canopy; (ii) facultative holoepiphytes (HLF) (casual): species that germinate and reproduce either on trees or in other substrates; (iii) accidental holoepiphytes (HLA): usually terrestrial, saxicolous, or epilithic species that occasionally grow on trees and are able to reproduce in the canopy. For the alternative or main habitat of the HLF and HLA terminology, we followed Barfuss et al. (2016): terrestrial, plants that grow on the ground and root into the substrate (tr); epilithic, plants which grow over bare rocks (el), and saxicolous, plants which root in rocks crevices or into the substrate accumulated between rocks (sx), respectively.

Geographic distribution data refers to the departments where the species were registered based on herbarium specimens and field observations, and is abbreviated as follows: Artigas: AR; Canelones: CA; Cerro Largo: CL; Colonia: CO; Durazno: DU; Flores: FS; Florida: FA; Lavalleja: LA; Maldonado: MA; Montevideo: MO; Pay: PA; Río Negro: RN; Rivera: RI; Rocha: RO; Salto: SA; San José: SJ; Soriano: SO; Tacuarembó: TA, and Treinta y Tres: TT. Additionally, the distribution in neighboring regions of Uruguay was investigated in order to detect the southernmost limit for each species; for this purpose we consulted several online databases (GBIF 2018; SPLink 2018; Flora do Brasil 2020 2019; IBODA 2019), publications concerning vascular epiphytes (Bauer \& Waechter 2011; Perleberg et al. 2013; Carneiro et al. 2016; Gonzatti et al. 2016; Machado et al. 2016; Martínez et al. 2016; Guerrero \& Cellini 2017; Pellegrini 2018), and in some cases data from herbarium labels. Habitat distribution follows the forest classification previously described (see Study area).

The assessment of the conservation status of each species follows the classification system proposed by IUCN (2012): Least Concern (LC), Near Threatened (NT), Vulnerable (VU), Endangered (EN) and Critically Endangered (CR). The evaluation of IUCN categories at the national level was based essentially on the geographic range criterion, through the assessment of Area of Occupancy (AOO) (IUCN 2012). We used AOO because most epiphytic species of Uruguay show a discontinuous geographic distribution. To assess it, we used the software GeoCAT-Geospatial Conservation Assessment Tool (Bachman et al. 2011) with a cell width of $15 \mathrm{~km}$, except for a few species whose habitat has low surface and so a cell width of $10 \mathrm{~km}$ was used: Asplenium gastonis Fée, Didymoglossum hymenoides (Hedw.) Copel., Niphidium crassifolium (L.) Lellinger, Pecluma paradiseae (Langsd. \& Fisch.) M.G. Price, Polyphlebium angustatum (Carmich.) Ebihara \& Dubuisson, Rhipsalis floccosa Salm-Dyck ex Pfeiff., Tillandsia arequitae (André) André ex Mez, T. loliacea Mart. ex Schult. f. in Roem. \& Schult., T. tricholepis Baker, T. uruguayensis Rossado and T. xiphioides Ker Gawl. For those species under any threatened category, the occurrence in national protected areas (SNAP) was evaluated.

\section{Results}

\section{Vascular epiphytic flora of Uruguay}

The epiphytic flora of Uruguay comprised 73 species, distributed in 29 genera and 12 families. Angiosperms were represented by 48 species, 16 genera and six families, whereas ferns by 25 species, 13 genera and six families. The richest families were Bromeliaceae (17 spp.), Polypodiaceae (16 spp.) and Orchidaceae (12 spp.), followed by Piperaceae (seven spp.) and Cactaceae (six spp.) (Fig. 2). On the whole, the three richest families constitute $62 \%$ of the epiphytic flora of the country. Tillandsia stood out as the most speciose genus with 15 species, more distantly followed by Peperomia (seven spp.) and Pleopeltis Humb. \& Bonpl. ex Willd. (five spp.).

Among the epiphytic categories (Fig. 3) characteristic holoepiphytes (Figs. 4,5) were the most diversified, with 46 species ( $63 \%$ ); most of these species occur within Bromeliaceae, Polypodiaceae and Orchidaceae. Second were the accidental holoepiphytes (Fig. 6), represented by 16 species ( $22 \%)$, followed by facultative holoepiphytes (Fig. 7), represented by nine species (12\%), in both cases belonging to different families. The two remaining species (3\%) occurred as hemiepiphytes (Fig. 8), both belonging to the genus Ficus L. (Moraceae).

All the species registered as epiphytes in natural environments are native to Uruguay, i.e., no alien species established in natural forests. Only two accidental epiphytic species of Tillandsia (Bromeliaceae) are endemic to the country, T. arequitae and T. uruguayensis. These species are essentially epilithic, but occasionally grow as epiphytes on trees close to the rocky surfaces, where they are abundant. Out of the non-endemic epiphytic species, slightly more than half $(53 \%)$ reached in Uruguay their southernmost limit of distribution. 
The conservation status assessment indicated a high extinction risk concerning the epiphytic flora, with 33 species ( $45 \%$ ) classified as threatened; 16 species (22\%) as VU and 17 species (23\%) as EN. Another set with 40 species (55\%) were outside of any threat, being classified in the LC and NT categories. Among the species identified as threatened, 20 have been reported for national protected areas.

\section{Species catalogue}

Ferns

\section{Aspleniaceae}

\section{Asplenium L.}

Asplenium gastonis Fée, Crypt. Vasc. Brésil 1. 70 t. 19 f. 2.1869.

= Asplenium divergens Mett. ex Baker in Mart., Fl. bras. 1(2): 445. 1870.

(Fig. 7D).

Epiphytic category: HLF (sx).

Distribution: CL, DU, RI, TA, TT. Uruguay is the southern limit of distribution.

Habitat: moist hillside forests, riverside forests and xeric hillside forests.

Conservation status: NT.

Observations: the species is common in the ravines of northeastern Uruguay, but scarce towards the east.

Voucher: Picasso \& Scarlato s.n. (MVJB 21875).

Asplenium sellowianum C. Presl ex Hieron., Hedwigia 60: 222. 1918. $\equiv$ Asplenium ulbrichtii Rosenst. var. sellowianum (Hieron.) Osten \& Herter, A. Mus. Hist. Nat. 2 (1): 349. 1925.
三Asplenium lunulatum Sw. var. sellowianun Hieron., Bot. Jahrb. Syst. 22 (3): 377. 1896.

= Asplenium ulbrichtii Rosenst. var. tenerrimum (Hieron.) Osten \& Herter, A. Mus. Hist. Nat. 2 (1): 349.1925

$\equiv$ Asplenium lunulatum Sw. var. tenerrima Hieron., Bot. Jahrb. Syst. 22(3): 377-378. 1896.

- Asplenium sellowianum C. Presl., Tent. Pterid. 107. 1836, nom. nudum.

Epiphytic category: HLA (tr, sx).

Distribution: AR, CL, DU MA, RI, SO, TA, TT.

Habitat: moist hillside forest, riverside forest and xeric hillside forest.

Conservation status: LC.

Observations: even when most herbarium records are from eastern Uruguay, it is a widely distributed species in Uruguay, possibly present throughout the country.

Taxonomic comment: there are different interpretations of the correct nomenclature for this species, but we follow Ganem et al. 2016 name proposal and lectotypification.

Voucher: Brussa et al. s.n. (MVJB 29867).

Asplenium ulbrichtii Rosenst., Hedwigia 43: 220. 1904.

= Asplenium ulbrichtii var. major Rosenst., Hedwigia 46: 99. 1906.

= Asplenium ulbrichtii var. serrato-dentatum Rosenst., Hedwigia 46: 99. 1906.

Epiphytic category: HLA (tr).

Distribution: AR, CA, CL, CO, DU, FA, LA, MA, PA, RI, SA, SJ, SO, TA, TT.

Habitat: moist hillside forests, riverside forests and xeric hillside forests.

Conservation status: LC.

Voucher: Berro 5214 (MVFA).
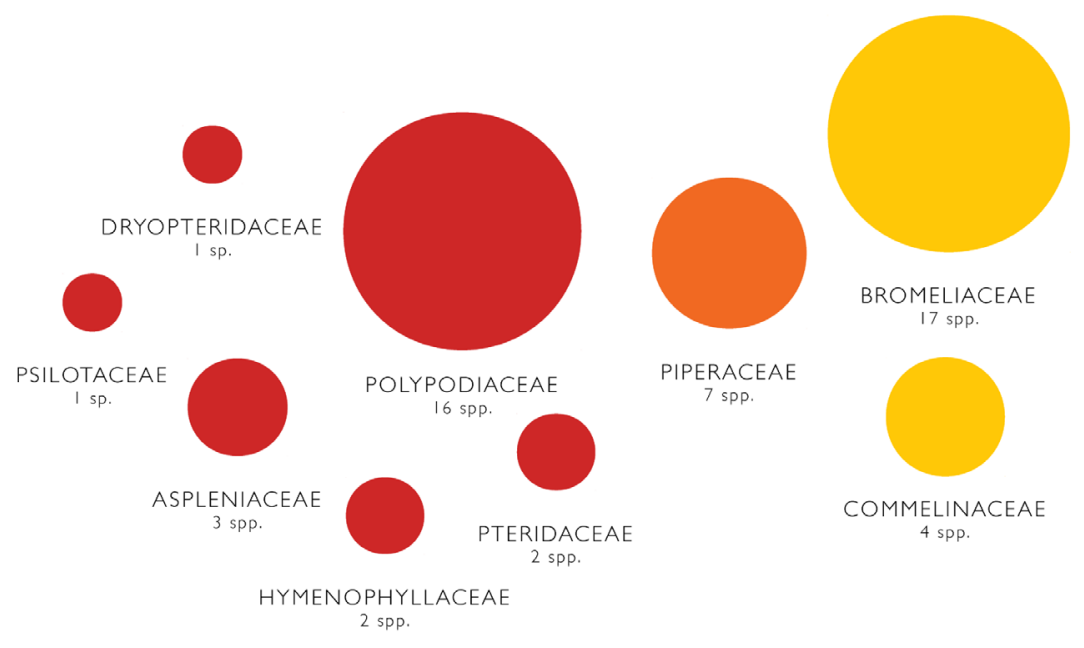
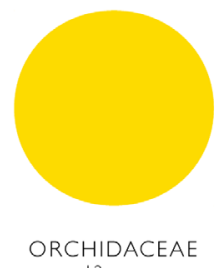

$12 \mathrm{spp}$.

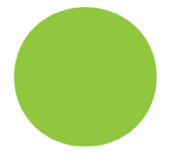

CACTACEAE

MORACEAE 2 spp.

Figure 2. Number of epiphytic species per vascular families in the flora of Uruguay. 


\section{Dryopteridaceae}

\section{Rumohra Raddi}

Rumohra adiantiformis (G. Forst.) Ching, Sinensia 5: 70.1934 $\equiv$ Polystichum adiantiforme (G. Forst.) J. Sm., Hist. Fil. 220. $1875 \equiv$ Polypodium adiantiforme G. Forst., Fl. Ins. Austr. 82. 1786.

= Aspidium capense Willd. Sp. Pl., ed. 4, 5: 267. 1810, nom. illeg. non Swartz 1801.

(Fig. 6B).

Epiphytic category: HLA (tr).

Distribution: CA, CL, CO, DU, FS, FA, LA, MA, MO, RN, RI, RO, SJ, SO, TA.

Habitat: Butia palm forests, moist hillside forests, psammophilous forests, riverside forests and xeric hillside forests.

Conservation status: LC.

Voucher: Delfino et al. s.n. (MVJB 21194).

\section{Hymenophyllaceae}

\section{Didymoglossum Desv.}

Didymoglossum hymenoides (Hedw.) Copel., Philipp. J. Sci. 67: 77. 1938 = Trichomanes hymenoides Hedw., Fil. Gen. Sp. t. 3, f. 3d-e. 1799.

$=$ Trichomanes pabstianum C. Mueller, Bot. Zeitung (Berlin) 12: 738. 1854.

(Fig. 6F).

Epiphytic category: HLF (el).

Distribution: $\mathrm{CL}, \mathrm{RO}, \mathrm{TA}$. Uruguay is the southern limit of distribution.

Habitat: moist hillside forests and xeric hillside forests.

Conservation status: VU. The species is considered as a priority for conservation in Uruguay by Marchesi et al. (2013), and occurs in the protected area 'Paisaje Protegido Paso Centurión y Sierra de Ríos'.

Observations: due to its small size, the species is probably under-represented in the national collections, and therefore information on current distribution and habitat occupied in Uruguay here presented could be under-estimated.

Voucher: Mai et al. 334 (MVJB).

Polyphlebium Copel.

Polyphlebium angustatum (Carmich.) Ebihara \& Dubuisson, Blumea 51(2): 240. 2006. $\equiv$ Trichomanes angustatum Carmich., Trans. Linn. Soc. London 12: 513. 1819.

= Trichomanes tenerum Spreng., Syst. Veg. 4: 129.1827. (Fig. 7A).
Epiphytic category: HLF (el).

Distribution: CL, DU, MA, RI, RO, TA, TT. Uruguay is the southern limit of distribution.

Habitat: moist hillside forests and xeric hillside forests.

Conservation status: VU. The species is considered as a priority for conservation in Uruguay by Marchesi et al. (2013), and occurs in the protected area 'Paisaje protegido Valle del Lunarejo'.

Observations: the specimens with epiphytic habit were mainly collected over the arborescent fern Dicksonia sellowiana Hook, which coincides with reports from southern Brazil (Buzatto et al. 2008).

Voucher: Brussa et al. s.n. (MVJB 21196).

\section{Polypodiaceae}

Campyloneurum $C$. Presl.

Campyloneurum nitidum (Kaulf.) C. Presl., Tent. Pterid. 190. 1836. $\equiv$ Polypodium nitidum Kaulf., Enum. Filic. 92. 1824.

= Campyloneurum major (Hieron. ex Hicken) Lellinger, Amer. Fern J. 78: 26. 1988. 三 Polypodium phyllitidis L. fo. major Hieron. ex Hicken, Revista Mus. La Plata 15: 272. 1908.

- Polypodium phyllitidis auct. non. L.: Osten \& Herter (1925); Herter (1928; 1939; 1949); Legrand \& Lombardo (1958).

(Fig. 7E).

Epiphytic category: HLF (sx, el).

Distribution: AR, CL, DU, LA, MA, MO, RI, RO, TA, TT. Uruguay is the southern limit of distribution.

Habitat: moist hillside forest, riverside forest and xeric hillside forest.

Conservation status: LC.

Taxonomic comment: in Uruguay Campyloneurum nitidum was for a long time considered under the name Polypodium phyllitidis L. ( $\equiv$ C. phyllitidis (L.) C. Presl.) (Osten \& Herter 1925; Herter 1928; 1939; 1949; Legrand \& Lombardo 1958). Lellinger (1988) argues that there has been

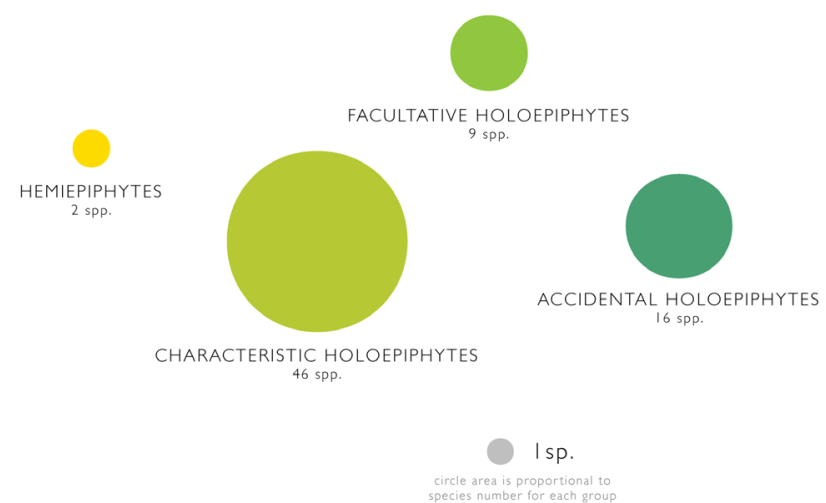

Figure 3. Number of epiphytic species in the vascular flora of Uruguay according to distinct adaptive categories. 

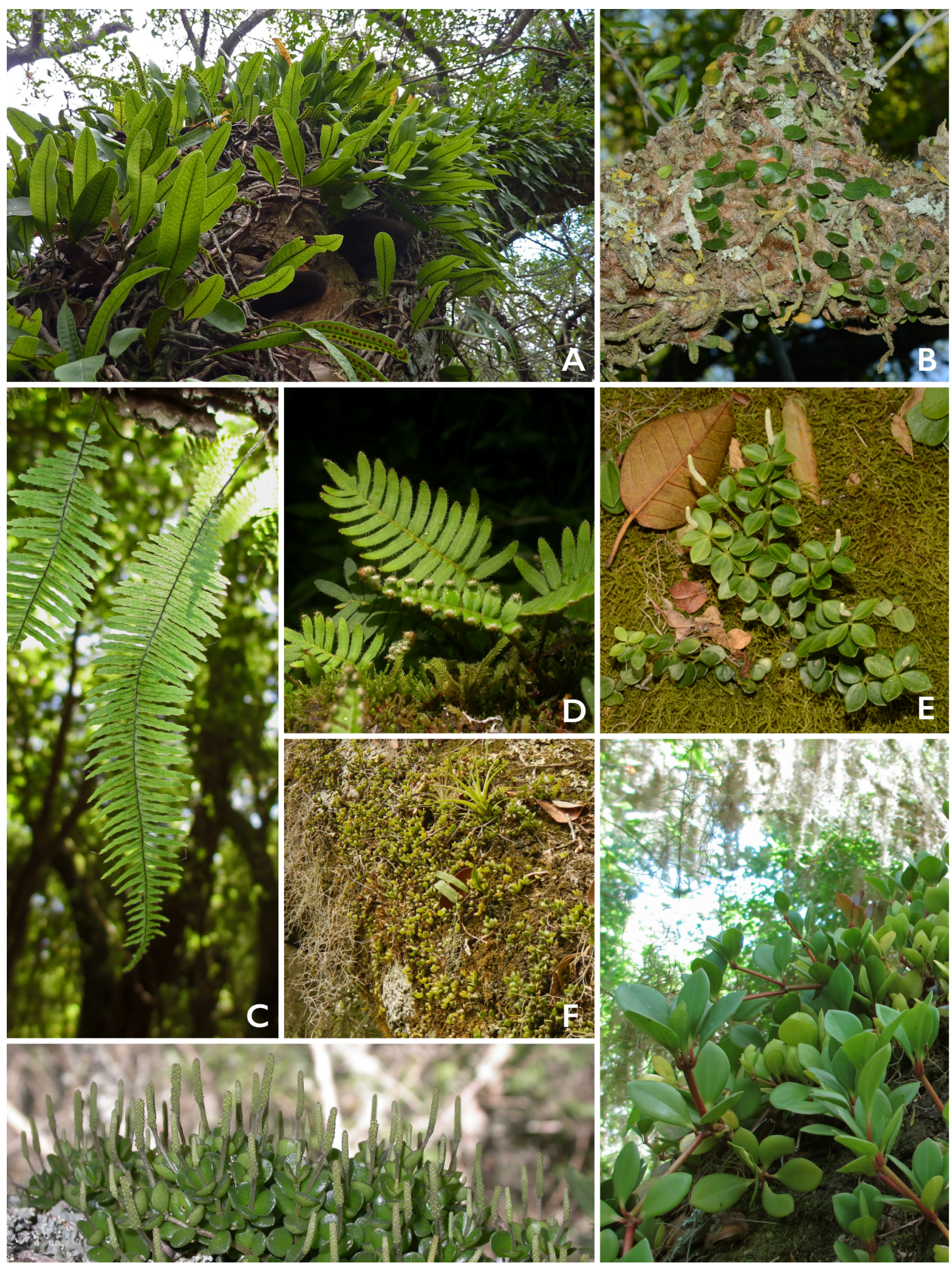

Figure 4. Characteristic holoepiphytes: A. Microgramma squamulosa. B. M. vacciniifolia. C. Pecluma sicca. D. Pleopeltis minima. E. Peperomia tetraphylla. F. P. psilostachya. G. P. catharinae. H. P. pereskiifolia. 


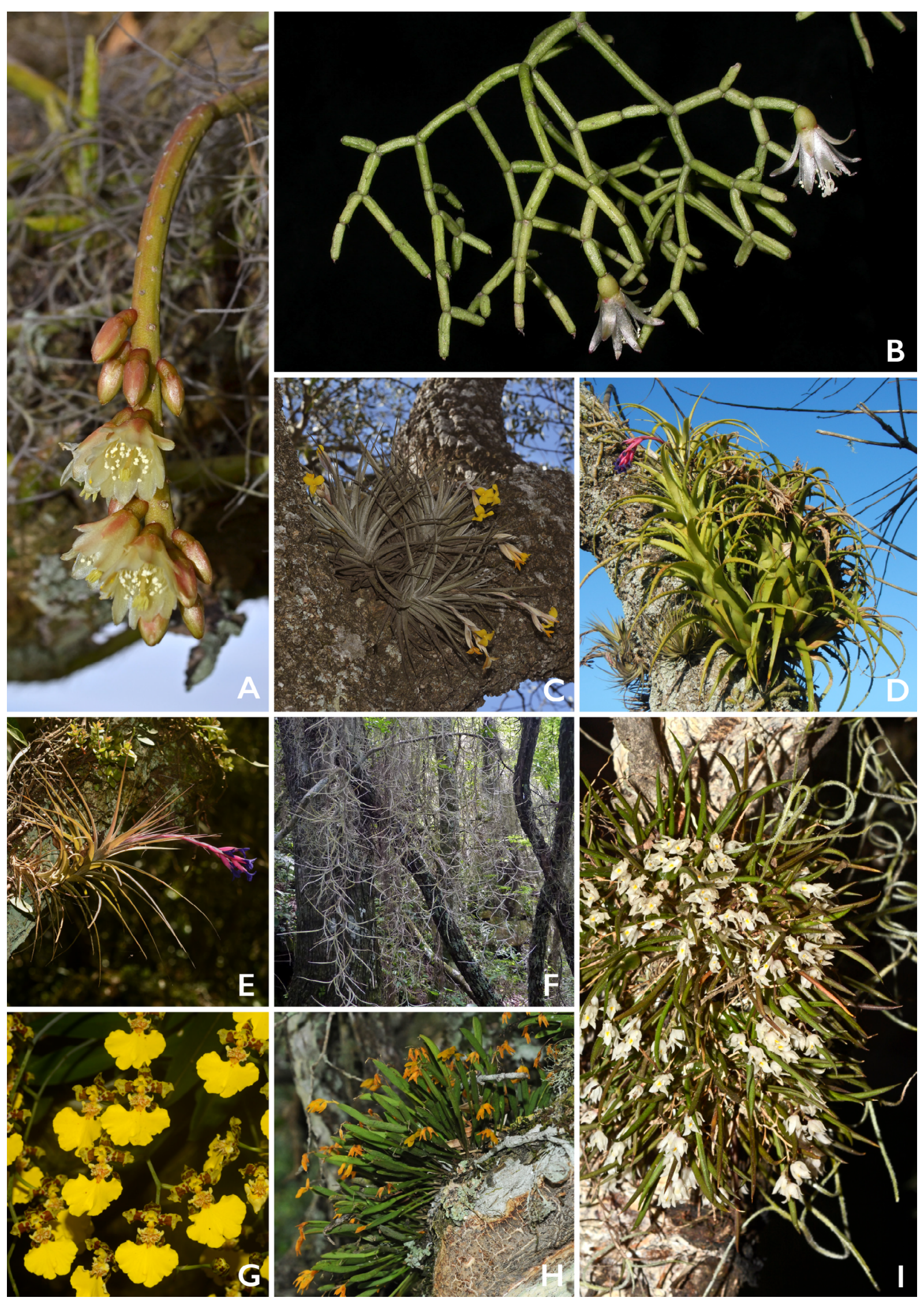

Figure 5. Characteristic holoepiphytes: A. Lepismium lumbricoides. B. Rhipsalis cereuscula. C. Tillandsia ixioides. D. Aechmea recurvata and T. aëranthos. E. T. aëranthos. F. T. usneoides. G. Gomesa bifolia. H. Acianthera sonderiana. I. Capanemia micromera. 

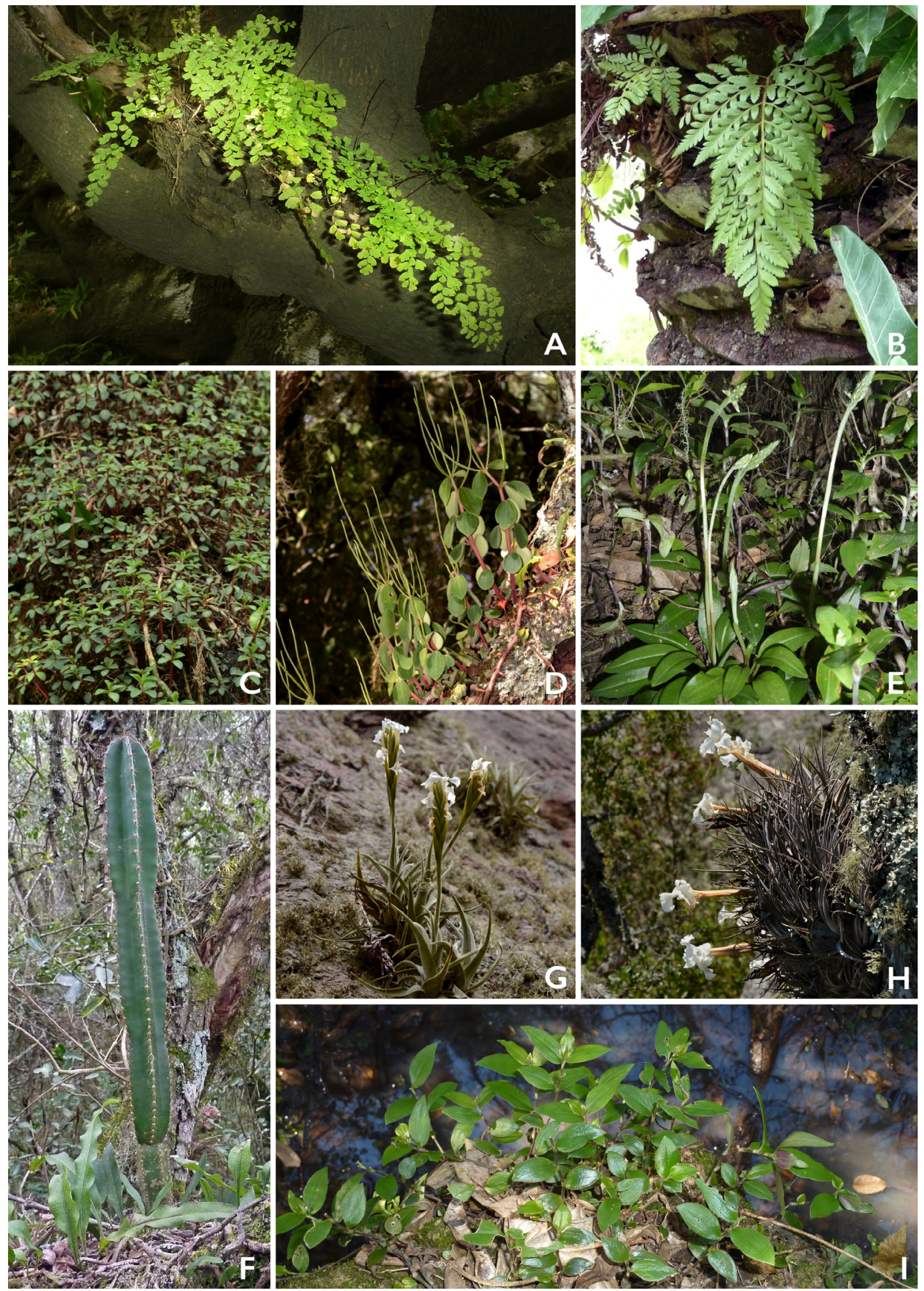

Figure 6. Accidental holoepiphytes: A. Adiantum raddianum. B. Rumohra adiantiformis. C. Peperomia comarapana. D. P. increscens. E. Cyclopogon elatus. F. Cereus hildmannianus subsp. uruguayanus. G. Tillandsia arequitae. H. T. xiphioides I. Tradescantia mundula. 

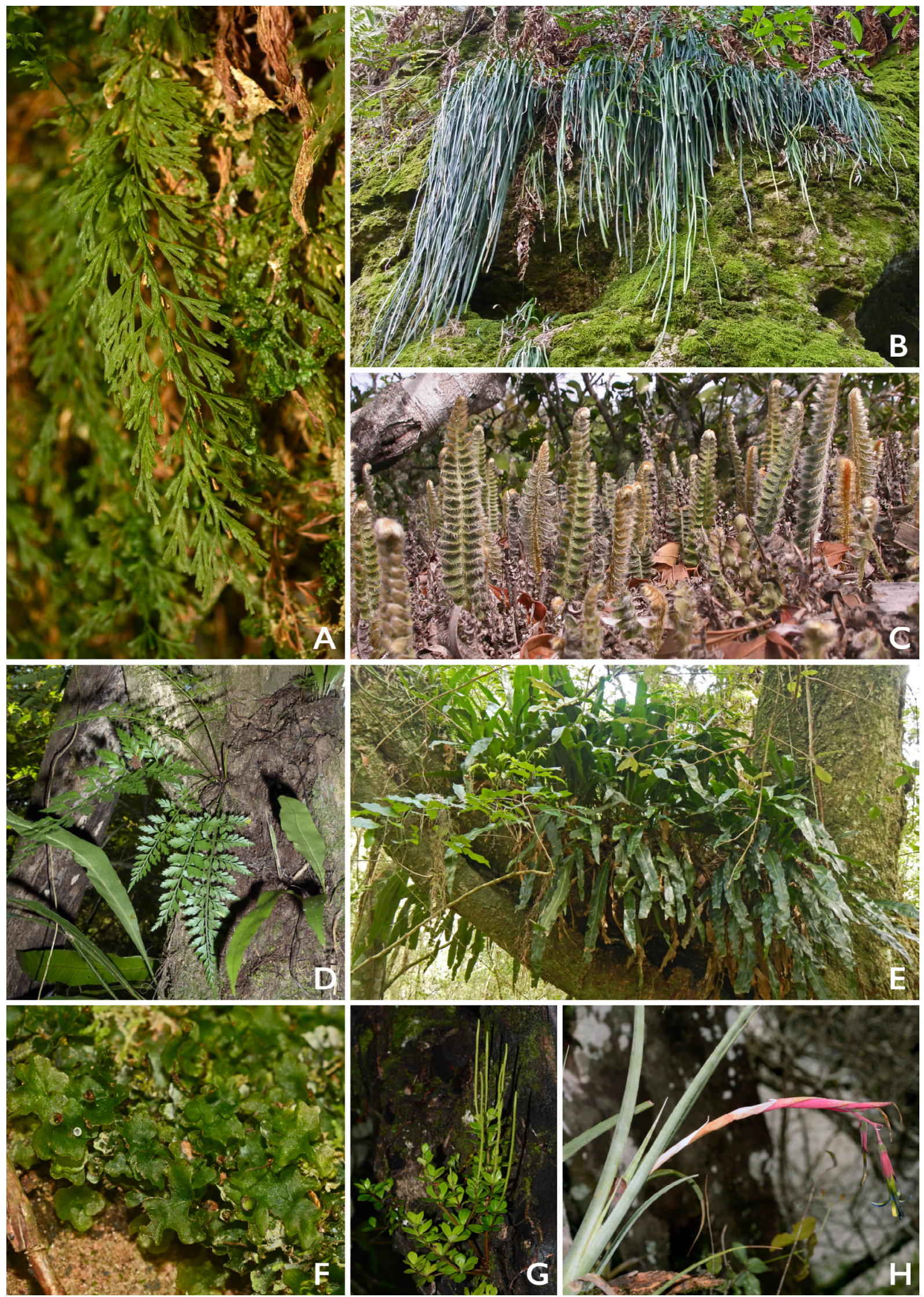

Figure 7. Facultative holoepiphytes: A. Polyphlebium angustatum. B. Vittaria lineata. C. Pleopeltis lepidopteris D. Asplenium gastonis. E. Campyloneurum nitidum. F. Didymoglossum hymenoides. G. Peperomia trineuroides. H. Billbergia nutans. 

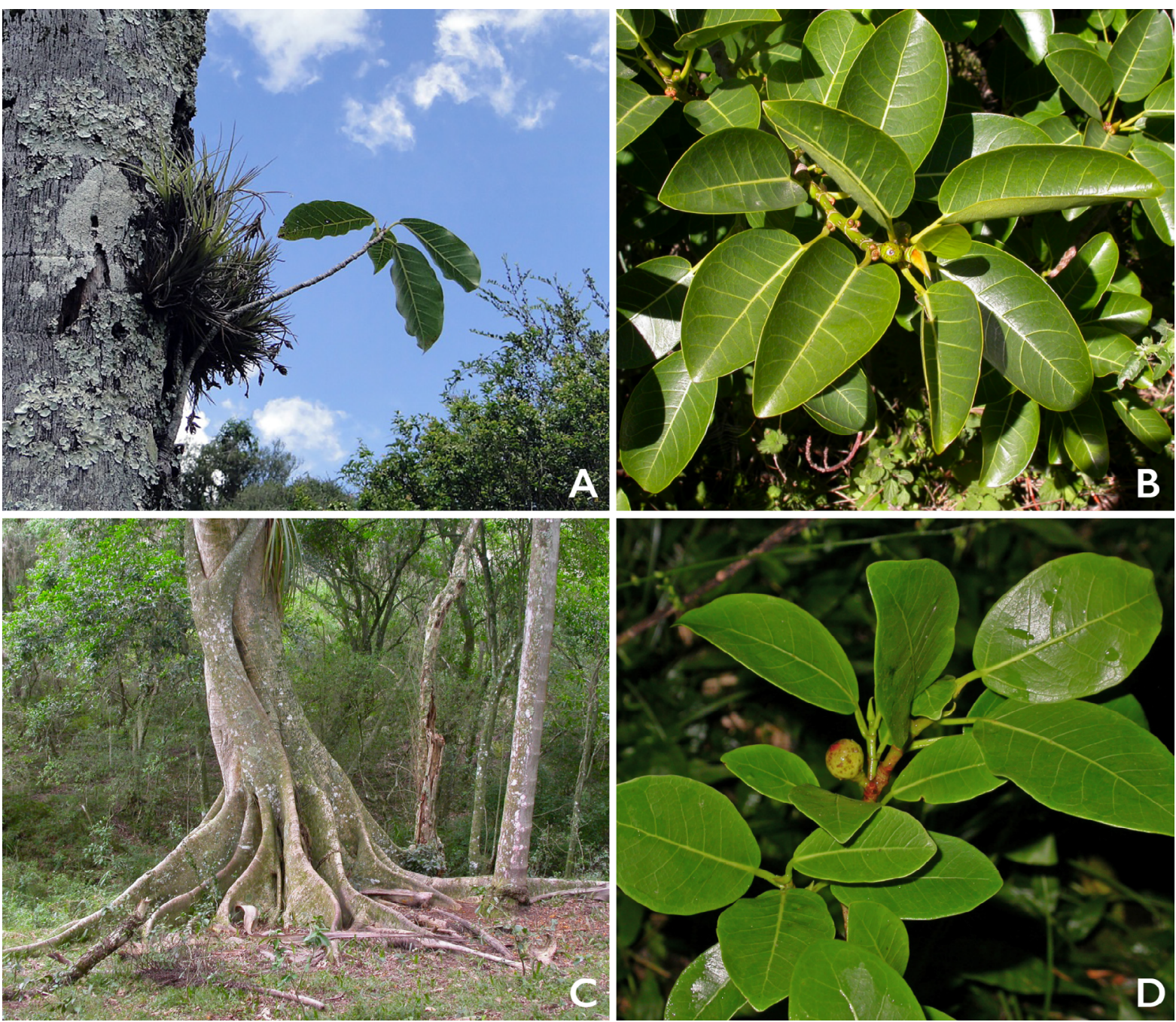

Figure 8. Hemiepipytes: A, B. Ficus luschnathiana. C, D. F. cestrifolia.

confusion between both species and discards the presence of C. phyllitidis in southern Brazil, Paraguay, Uruguay and Argentina, an opinion more recently also shared by Vasques \& Prado (2011). We were able to corroborate that specimens deposited at national herbaria and identified as C. phyllitidis from a morphological standpoint correspond with $C$. nitidum. Campyloneurum nitidum exccicates were also studied at ICN, and the morphological characteristics observed there matched those of the Uruguayan specimens.

Voucher: Brussa \& Grela s.n. (MVJB 26612).

\section{Microgramma C. Presl.}

Microgramma mortoniana de la Sota, Am. Fern. J. 63: 64. 1973.

Epiphytic category: HLC.

Distribution: AR, CO, PA, RN, SO.

Habitat: Butia palm forests, hydrophilous forests, open thorn forests, psammophilous forests, riverside forests and xeric hillside forests.
Conservation status: NT.

Observations: the species is only present in the west of the country, and most records are concentrated in a few localities of the southwest.

Voucher: Rosengurtt et al. 10503 (MVFA).

Microgramma squamulosa (Kaulf.) de la Sota, Opera Lilloana 5: 59, f. 2, 3, 6, 7. 1960. झMarginaria squamulosa (Kaulf.) Herter, Revista Sudamer. Bot. 6: 131. 1940. $\equiv$ Polypodium lycopodioides L. var. squamulosum (Kaulf.) Baker, Fl. Bras. (Martius) 1(2): 534. 1870. $\equiv$ Pleopeltis squamulosa (Kaulf.) C. Presl., Tent. Pterid. 193. 1836. $\equiv$ Polypodium squamulosum Kaulf., Enum. Filic. 89. 1824.

- Polypodium lycopodioides auct. non. L.: Legrand \& Lombardo (1958).

(Fig. 4A).

Epiphytic category: HLC.

Distribution: AR, CA, CL, CO, DU, FA, LA, MA, MO, PA, RN, SA, SJ, SO, TA, TT. Uruguay is the southern limit of distribution. 
Habitat: hydrophilous forest, moist hillside forest, psammophilous forest, riverside forest and xeric hillside forest.

Conservation status: LC.

Observations: this is one of the most common and widely distributed epiphytic species.

Voucher: Arechavaleta s.n. (MVM 415).

Microgramma vacciniifolia (Langsd. \& Fisch.) Copel., Gen. Fil. 185. 1947. $\equiv$ Marginaria vacciniifolia (Langsd. \& Fisch.) C. Presl, Tent. Pterid. 188. 1836. $\equiv$ Polypodium vacciniifolium Langsd. \& Fisch., Pl. Voy. Russes Monde 8, pl. 7. 1810.

(Fig. 4B).

Epiphytic category: HLC.

Distribution: AR, CA, CL, DU, FA, MA, MO, PA, RI, RN, RO, SA, SJ, TA.

Habitat: hydrophilous forests, moist hillside forests, psammophilous forests, riverside forests and xeric hillside forests.

Conservation status: LC.

Voucher: Del Puerto \& Marchesi 3623 (MVFA).

Niphidium J. Sm.

Niphidium crassifolium (L.) Lellinger, Amer. Fern J. 62: 106 - 107. 1972. झ Polypodium crassifolium L., Sp. Pl. 2: 1083. 1753.

Epiphytic category: HLF.

Distribution: CL. Uruguay is the southern limit of distribution.

Habitat: moist hillside forest.

Conservation status: EN. The species is considered as a priority for conservation in Uruguay by Marchesi et al. (2013), and occurs in the protected area 'Paisaje Protegido Paso Centurión y Sierra de Ríos'.

Observations: the species has been poorly sampled in the country (three herbarium specimens). All the specimens were collected in moist hillside forests in eastern Uruguay where they grow preferentially on cliffs, and only one epiphytic plant was recorded and collected over a big Luehea divaricata Mart. tree, on large branches forming a circular population.

Voucher: Mai et al. 331 (MVJB).

Pecluma M.G. Price.

Pecluma filicula (Kaulf.) M.G. Price, Am. Fern. J. 73(4): 114. 1983. 三Polypodium filiculum Kaulf. Enum. Filic. 275.1824.

Epiphytic category: HLC.

Distribution: RI. Uruguay is the southern limit of distribution.
Habitat: moist hillside forests.

Conservation status: EN. The species is considered as a priority for conservation in Uruguay by Marchesi et al. (2013), but is absent in national protected areas.

Observation: we include P. filicula in the epiphytic flora of Uruguay because within its natural range and in neighboring areas of Uruguay it grows as holoepiphyte (Evans 1969; Márquez et al. 2006; Cervi \& Borgo 2007; Torres et al. 2013; Martínez et al. 2016). However, only two exsiccates of this species exists in the country (MVM 4195 and MVFA 27662), of which one of them (MVM 4195) is ancient and lacks collection data (date, environment and locality); therefore, information about this species is limited. We hypothesize that this species must occur in Uruguay in well preserved, isolated and remote habitats, which have kept the species from being gathered by recent collectors.

Voucher: Bonifacino et al. s.n. (MVFA 27662).

Pecluma paradiseae (Langsd. \& Fisch.) M.G. Price, Am. Fern. J. 73(4): 115. 1983. झ Polypodium paradiseae Langsd. \& Fisch., Pl. Voy. Russes Monde 11, pl. 11. 1810.

Epiphytic category: HLC.

Distribution: RI, TA.

Habitat: moist hillside forests.

Conservation status: EN. The species is not included as a priority for conservation in Uruguay by Marchesi et al. (2013). The species occurs in the protected area 'Paisaje protegido Valle del Lunarejo'. Therefore, we consider it relevant to add $P$. paradiseae to the list of species considered as priority for conservation in Uruguay.

Observations: the species has been collected in only two nearby localities in northeastern Uruguay.

Voucher: Brussa et al. s.n. (MVJB 28285).

Pecluma pectinatiformis (Lindm.) M.G. Price, Am. Fern. J. 73 (4):115. 1983. 三 Polypodium pectinatiforme Lindm., Hedwigia 43: 309. 1904.

Epiphytic category: HLC.

Distribution: RI.

Habitat: moist hillside forest. It occurs exclusively in ravines in northeastern Uruguay.

Conservation status: EN. The species is considered as a priority for conservation in Uruguay by Marchesi et al. (2013), and occurs in the protected area 'Paisaje protegido Valle del Lunarejo'.

Voucher: Picasso \& Scarlato s.n. (MVJB 21404).

Pecluma sicca (Lindm.) M.G. Price, Am. Fern. J. 73(4): 115. 1983. $\equiv$ Polypodium siccum Lindm., Ark. Bot. 1: 234, pl. 11, f. 4. 1903.

(Fig. 4C).

Epiphytic category: HLC. 
Distribution: AR, CL, MA, RI. TA. TT. Uruguay is the southern limit of distribution.

Habitat: moist hillside forests and xeric hillside forests.

Conservation status: NT; nevertheless, it is still a species that is considered as a priority for conservation in the country (Marchesi et al. 2013).

Voucher: Marchesi s.n. (MVFA 1072).

Pleopeltis Humb. \& Bonpl. ex Willd.

Pleopeltis hirsutissima (Raddi) de la Sota, Darwiniana 45 (2): 239. 2007. $\equiv$ Polypodium hirsutissimum Raddi., Opusc. Sci. 3: 286. 1819.

= Polypodium rufulum C. Presl., Delic. Prag. 1: 164.1822

Epiphytic category: HLC.

Distribution: AR, CL, MA, RI. RO, RN, TA, TT. Uruguay is the southern limit of distribution.

Habitat: Butia palm forest, moist hillside forest and xeric hillside forest.

Conservation status: LC.

Voucher: Herter s.n. (Herb. Osten 18595, MVM).

Pleopeltis lepidopteris (Langsd. \& Fisch.) de la Sota, Darwiniana 45 (2): 239. 2007. 三 Polypodium lepidopteris (Langsd. \& Fisch.) Kunze., Linnaea 13: 132. 1839. $\equiv$ Acrostichum lepidopteris Langsd. \& Fisch., Pl. Voy. Russes Monde 5, pl. 2. 1810.

(Fig. 7C).

Epiphytic category: HLF (sx, el).

Distribution: AR, CL, DU, LA, MA, RI, RO, TA, TT. Uruguay is the southern limit of distribution.

Habitat: moist hillside forests, psammophilous forests and xeric hillside forests.

Conservation status: LC.

Voucher: Marchesi 583 (MVFA).

Pleopeltis macrocarpa (Bory ex Willd.) Kaulf., Berlin. Jahrb. Pharm. Verbundenen Wiss. 21: 41. 1820. $\equiv$ Polypodium macrocarpum Bory ex Willd., Sp. Pl. Editio quarta 5(1): 147. 1810.

$=$ Marginaria lanceolata $($ L.) Herter, Revista Sudamer. Bot. 6: 131. 1940. $\equiv$ Pleopeltis lanceolata (L) Kaulf. Enum. Filic. 245. $1824 \equiv$ Polypodium lanceolatum L. Sp. Pl. 2: 1082. 1753.

Epiphytic category: HLC.

Distribution: MA, RO.

Habitat: hydrophilous forest, moist hillside forest, psammophilous forest, riverside forest and xeric hillside forest.

Conservation status: NT; nevertheless it is a species considered as a priority for conservation in the country (Marchesi et al. 2013).
Voucher: Arechavaleta s.n. (MVM 4199).

Pleopeltis minima (Bory) J. Prado \& R.Y. Hirai, Am. Fern. J. 100 (4): 191. 2010. 三Polypodium polypodioides (L.) Watt var. minimum (Bory) Kuhlm. \& Kuhn, Fl. Distr. Ibiti: 22. 1948 三 Polypodium minimum (Bory) Herter, Anales Mus. Nac. Montevideo, ser. 2, 1: 368, tab. 28. 1925, nom. illeg. non Aublet $1775 \equiv$ Marginaria minima Bory., Dict. Class. Hist. Nat. 10: 177. 1826.

= Polypodium polypodioides (L.) Watt var. minus (Fée) Weath., Contr. Gray Herb. 124: 31. 1939.

= Pleopeltis squalida (Vell.) de la Sota., Hickenia 3(46): 196. $2003 \equiv$ Polypodium incanum Sw. var. squalidum (Vell.) Baker., Fl. Bras. 1(2): 526. $1870 \equiv$ Polypodium squalidum Vell. Arch. Mus. Nac. Rio de Janeiro 5: 449. 1881.

= Marginaria dielsii Herter, Revista Sudamer. Bot. 6: 130. 1940.

= Marginaria microlepis (Fée) Herter, Revista Sudamer. Bot. 6: 130. 1940. $\equiv$ Polypodium microlepis Fée, Mém. Foug. 238. 1850.

(Fig. 4D).

Epiphytic category: HLC.

Distribution: AR, CL, CO, DU, FA, PA, RN, RI, RO, SA, SO, TA.

Habitat: moist hillside forests, open thorn forests, riverside forests and xeric hillside forests.

Conservation status: LC.

Voucher: Zúñiga s.n. (Herb. Gibert, MVM 4201).

Pleopeltis pleopeltifolia (Raddi) Alston, Bol. Soc. Brot. Sér. 2 30: 21. 1956. $\equiv$ Polypodium pleopeltifolium Raddi, Opusc. Sci. 3: 286. 1819.

= Polypodium angustum (Humb. \& Bonpl. ex Willd.) Liebm., Kongel. Danske Vidensk. Selsk. Skr., Naturvidensk. Math. Afd., ser. 5, 1: 186. 1849 三Pleopeltis angusta Humb. \& Bonpl. ex Willd. Sp. Pl. Editio quarta 5(1): 211. 1810.

Epiphytic category: HLC.

Distribution: AR, CA, CL, CO, DU, FA, LA, MA, PA, RN, RI, RO, SA, SJ, SO, TA, TT.

Habitat: hydrophilous forest, moist hillside forest, riverside forest and xeric hillside forest.

Conservation status: LC.

Observations: this is one of the most common and widely distributed epiphytic species in Uruguay.

Voucher: Osten 3100 (MVM).

Serpocaulon A.R. Sm.

Serpocaulon catharinae (Langsd. \& Fisch.) A.R. Sm., Taxon 55 (4): 928. 2006. 三 Polypodium catharinae Langsd. \& Fisch., Pl. Voy. Russes Monde 1, pl. 9. 1810.

Epiphytic category: HLC. 
Distribution: CA, MA, RO, SJ, TT. Uruguay is the southern limit of distribution.

Habitat: Butia palm forests, hydrophilous forests, moist hillside forests, riverside forests and xeric hillside forests.

Conservation status: LC.

Voucher: Del Puerto \& Marchesi 6107 (MVFA).

Serpocaulon latipes (Langsd. \& L. Fisch.) A.R. Sm., Taxon 55 (4): 928. 2006. $\equiv$ Polypodium latipes Langsd. \& Fisch., Pl. Voy. Russes Monde 1, pl. 10. 1810.

Epiphytic category: HLC.

Distribution: LA, MA, RO. Uruguay is the southern limit of distribution.

Habitat: Butia palm forests, moist hillside forests and riverside forests.

Conservation status: NT.

Observations: in the region (Argentina and Brazil) this species is generally terrestrial. However, in Uruguay most specimens grew as epiphytes, and for this reason it is assigned the HLC category.

Voucher: Brussa et al. s.n. (MVJB 27279).

\section{Pteridaceae}

\section{Adiantum L.}

Adiantum raddianum C. Presl., Tent. Pterid. 158. 1836.

=Adiantum cuneatum Langsd. \& Fisch., Ic. Fil.: 23, t. 26. 1810, nom. illeg. non Forst. 1786.

(Fig. 6A).

Epiphytic category: HLA (tr).

Distribution: AR, CA, CL, CO, DU, FA, LA, MA, MO, PA, RN, RI, RO, SA, SJ, SO, TA, TT.

Habitat: moist hillside forest, riverside forest and xeric hillside forest.

Conservation status: LC.

Voucher: Mai 149 (MVJB).

Vittaria Sm.

Vittaria lineata (L.) Sm., Mém. Acad. Roy. Sci. (Turin) 5 (1790-1791): 421, pl. 9, f. 5. 1793. EPteris lineata L., Sp. Pl. 2: 1073, 1753.

(Fig. 7B).

Epiphytic category: HLF (el, sx).

Distribution: CL, LA, MA, RI, RO, TA. Uruguay is the southern limit of distribution.

Habitat: Butia palm forests, moist hillside forests, riverside forests and xeric hillside forests.

Conservation status: LC.
Voucher: Marchesi s.n. (MVFA 14008).

\section{Psilotaceae}

Psilotum Sw.

Psilotum nudum (L.) P. Beauv., Prodr. Aethéogam. 106, 112 (1805) $\equiv$ Lycopodium nudum L., Sp. Pl. 2: 1100-1101. 1753.

Epiphytic category: HLC.

Distribution: RI, RO.

Habitat: Butia palm forest, moist hillside forest and riverside forest.

Conservation status: VU. The species is considered as a priority for conservation in Uruguay by Marchesi et al. (2013), and occurs in the protected area 'Paisaje protegido Valle del Lunarejo'.

Observations: this fern occurs in two disjunct areas in Uruguay, in the northeast and in the east of the country.

Voucher: Marchesi s.n. (MVFA 14026).

Angiosperms

\section{Bromeliaceae}

Aechmea Ruiz \& Pav.

Aechmea recurvata (Klotzsch) L.B.Sm., Contr. Gray Herb. 98: 5. 1932. $\equiv$ Macrochordium recurvata Klotzsch, Allg. Gartenzeitung 24: 393. 1856.

= Aechmea legrelliana (Baker) Baker, 17: 236. 1879. $\equiv$ Hohenbergia legrelliana Baker, Refug. Bot. 4: t. 285. 1871.

= Aechmea ampullacea Mez, Monogr. Phan. 9: 257. 1896.

(Fig. 5D).

Epiphytic category: HLC or HLF (sx).

Distribution: CL, RI, RO, TA, TT. Uruguay is the southern limit of distribution.

Habitat: Butia palm forests, hydrophilous forests, riverside forests, xeric hillside forests and moist hillside forests.

Conservation status: LC.

Observations: the epiphytic category of this species depends on the environment. In Butia palm forest, hydrophilous and riverside forest the species grows exclusively as an epiphyte (HLC), whereas in hillside forests it grows both as an epiphyte and as saxicolous (HLF).

Voucher: Berro 2054 (MVFA).

Billbergia Thunb.

Billbergia nutans $\mathrm{H}$. Wendl. ex Regel, Gartenflora 18: 162, t. 617. 1869.

(Fig. 7H). 
Epiphytic category: HLF (sx).

Distribution: AR, CL, RI, TA.

Habitat: moist hillside forest and riverside forest.

Conservation status: NT.

Voucher: Marchesi 999 (MVFA).

\section{Tillandsia L.}

Tillandsia aëranthos (Loisel.) L.B. Sm. Lilloa 9: 200.1943. $\equiv$ Pourretia aëranthos Loisel. Herb. Gén. Amat. 5: t. 304.1821. $=$ Tillandsia dianthoidea G. Rossi, Cat. Pl. Hort. Modoet. Ed. 2, 79: t. 1.1825 [1826].

= Tillandsia bicolor Brongn., Voy. Monde 2: 185: t. 36 . 1829 [1834].

=Tillandsia microxiphion Baker, Bot. Mag. 119: t. 7320 . 1893.

(Fig. 5D; 5E).

Epiphytic category: HLC.

Distribution: AR, CA, CL, CO, DU, FA, FS, LA, MA, MO, PA, RN, RI, RO, SA, SJ, SO, TA, TT.

Habitat: Butia palm forests, hydrophilous forests, moist hillside forests, open thorn forests, psammophilous forests, riverside forests and xeric hillside forests.

Conservation status: LC.

Observations: it is one of the most frequent and widely distributed epiphytic species in Uruguay.

Voucher: Osten 2880 (MVM).

Tillandsia arequitae (André) André ex Mez, Monogr. Phan. 9: 814. 1896. $\equiv$ Tillandsia xiphioides var. arequitae André, Rev. Hort. 65: 156. 1893.

(Fig. 6G).

Epiphytic category: HLA (el).

Distribution: LA, MA.

Habitat: xeric hillside forests.

Conservation status: VU. The species is considered as a priority for conservation in Uruguay by Marchesi et al. (2013), but is absent in national protected areas.

Observations: the species is an endemic species of Uruguay, with a distribution restricted to the southeast of the country. It is rarely found as an epiphyte on trees close to the rocky surfaces where it is more abundant.

Voucher: Rossado 402 (MVFA).

Tillandsia bandensis Baker, J. Bot. 25: 234. 1887.

Epiphytic category: HLC or HLA (el).

Distribution: AR, CL, CO, RN, SA, SO, TT.

Habitat: hydrophilous forest, open thorn forest, xeric hillside forests.

Conservation status: NT.

Observations: the species presents two subspecies in two disjunct areas of Uruguay; T. bandensis subsp. grandipetala
Rossado occurs in eastern Uruguay, while the typical one occurs in the west of the country near the Uruguay River (Rossado et al. 2019). The epiphytic category varies in relation to these two areas, behaving as a HLC in the west and as HLA (el) in the east.

Voucher: Berro 4179 (MVFA).

Tillandsia duratii Vis., Nuovi Saggi Imp. Regia Accad. Sci. Padova 5: 271, t. 29. 1840.

Epiphytic category: HLC.

Distribution: AR, PA, SA.

Habitat: open thorn forests, riverside forests.

Conservation status: VU. The species is not included as a priority for conservation in Uruguay by Marchesi et al. (2013), and is absent in national protected areas. Additionally, the species is found in few localities within Uruguay, mainly associated with open thorn forest which is an endangered habitat in the country, therefore we consider it relevant to add $T$. duratii to the list of species considered as a priority for conservation in Uruguay.

Voucher: Berro 1328 (MVFA).

Tillandsia geminiflora Brongn., Voy. Monde 2:186. 1829 [1834].

Epiphytic category: HLC.

Distribution: CL, LA, RO, TT. Uruguay is the southern limit of distribution.

Habitat: hydrophilous forests, moist hillside forests, psammophilous forests, riverside forests and xeric hillside forests.

Conservation status: NT.

Voucher: Berro 2416 (MVFA).

Tillandsia ixioides Griseb. Abh. Königl. Ges. Wiss. Göttingen 24: 333. 1879.

(Fig. 5C).

Epiphytic category: HLC.

Distribution: AR, PA, RN, SJ.

Habitat: open thorn forest.

Conservation status: VU. The species is considered as a priority for conservation in Uruguay by Marchesi et al. (2013), but is absent in national protected areas.

Voucher: Berro 1657 (MVFA).

Tillandsia loliacea Mart. ex Schult. f. in Roem. \& Schult., Syst. Veg. 7(2): 1204. 1830.

Epiphytic category: HLC.

Distribution: AR. In the region, northern Uruguay and southern Corrientes (Argentina) represents the southern limit of distribution.

Habitat: open thorn forests. 
Conservation status: EN. The species is not included as a priority for conservation in Uruguay by Marchesi et al. (2013), and is absent in national protected areas. Therefore, we consider it relevant to add T. loliacea to the list of species considered as a priority for conservation in Uruguay, as it was suggested in Rossado et al. (2018b).

Observations: the species has been found only in one locality in Uruguay.

Voucher: Villagrán et al. s.n. (MVJB 30693).

Tillandsia myosura Griseb. ex Baker, J. Bot. 16: 240. 1878.

Epiphytic category: HLC.

Distribution: CO, LA, MA, RN, SA, SJ, SO.

Habitat: riverside forest, psammophilous forest, xeric hillside forest.

Conservation status: NT.

Taxonomic comment: some specimens collected in Uruguay have been misidentified and cited for the country under the name of T. crocata (E. Morren) Baker (Smith 1933; Marchesi 1965; Smith 1972; Smith \& Downs 1977).

Voucher: Osten 3055 (MVM).

Tillandsia recurvata (L.) L., Sp. Pl. (ed. 2) 1: 410. 1762. $\equiv$ Renealmia recurvata L., Sp. Pl. 1: 287. 1753.

Epiphytic category: HLC.

Distribution: AR, CA, CL, CO, DU, FA, FS, LA, MA, MO, PA, RI, RN, RO, SA, SJ, SO, TA, TT.

Habitat: hydrophilous forests, moist hillside forests, open thorn forests, psammophilous forests, riverside forests and xeric hillside forests.

Conservation status: LC.

Voucher: Osten 2943 (MVM).

Tillandsia recurvifolia Hook., Bot. Mag. 87: t. 5246. 1861.

- Tillandsia meridionalis auct. non Baker: Smith (1972); Smith \& Downs (1977).

Epiphytic category: HLC.

Distribution: AR, SA.

Habitat: open thorn forests.

Conservation status: EN. The species is considered as a priority for conservation in Uruguay by Marchesi et al. (2013), but is absent in national protected areas.

Observations: the species is restricted to northwestern Uruguay.

Taxonomic comment: the species has been erroneously identified as Tillandsia meridionalis Baker.

Voucher: Klappenbach s.n. (MVM 2948).

Tillandsia stricta Sol. ex Sims, Bot. Mag. 37: t. 1529. 1813. Epiphytic category: HLC.
Distribution: CL, RO, TT. Uruguay is the southern limit of distribution.

Habitat: moist hillside forest, riverside forest.

Conservation status: VU. The species is considered as a priority for conservation in Uruguay by Marchesi et al. (2013), and occurs in the protected area 'Paisaje Protegido Paso Centurión y Sierra de Ríos'.

Voucher: Berro 2417 (MVFA).

Tillandsia tricholepis Baker, J. Bot. 16: 237. 1878.

Epiphytic category: HLC.

Distribution: AR.

Habitat: open thorn forests.

Conservation status: EN. The species is not included as a priority for conservation in Uruguay by Marchesi et al. (2013), and is absent in national protected areas. Therefore, we consider it relevant to add T. tricholepis to the list of species considered as a priority for conservation in Uruguay.

Observations: the species was recently found in natural environments only in the department of Artigas. In Uruguayan herbaria, there are also specimens from suburban sites around the cities of Salto and Tacuarembó, and so they were not assessed in distribution and conservation status.

Voucher: Villagrán et al. s.n. (MVM 23003).

Tillandsia uruguayensis Rossado, Phytotaxa 345 (2): 134-137. 2018.

Epiphytic category: HLA (el).

Distribution: AR, RI, TA. The species is endemic to Uruguay with a restricted distribution in the northeast of the country, but could also occur in nearby Brazil.

Habitat: moist hillside forest, xeric hillside forest.

Conservation status: VU; due to its recent discovery (Rossado et al. 2018a) the species is not included as a priority for conservation in Uruguay by Marchesi et al. (2013). We consider it relevant to add T. uruguayensis to the list of species considered as priority for conservation in Uruguay. The species occurs in the protected area 'Paisaje protegido Valle del Lunarejo'.

Observations: the species is rarely found as an epiphyte in xeric hillside forest on trees close to the rocky surfaces where it is abundant.

Voucher: Rossado \& Bonifacino 418 (MVFA, WU).

Tillandsia usneoides (L.) L.,Sp. Pl. (ed. 2) 1: 411. 1762. $\equiv$ Renealmia usneoides L., Sp. Pl. 1: 287. 1753.

(Fig. 5F).

Epiphytic category: HLC.

Distribution: AR, CL, DU, FA, LA, MA, RI, RO, RN, SA, SO, TA, TT.

Habitat: hydrophilous forests, moist hillside forests, 
psammophilous forests and riverside forests.

Conservation status: LC.

Observation: the species probably has a wider distribution, so the current distribution is underrepresented due to low sampling.

Voucher: Osten 3121 (MVM).

Tillandsia xiphioides Ker Gawl., Bot. Reg. 2: t. 105. 1816.

(Fig. 6H).

Epiphytic category: HLA (el).

Distribution: CL, SJ.

Habitat: xeric hillside forest.

Conservation status: EN. The species is considered as a priority for conservation in Uruguay by Marchesi et al. (2013), but is absent in national protected areas.

Observations: the species occurs only in two localities in Uruguay, distant from one another. Tillandsia xiphioides is rarely found as an epiphyte on trees, close to the rocky surfaces where it is more abundant.

Voucher: Rossado et al. 24 (MVJB).

\section{Cactaceae}

\section{Cereus Mill.}

Cereus hildmannianus Schum. subsp. uruguayanus (Kiesling) Taylor, Cactaceae Consensus Init. 6: 15. 1998.

$=$ Cereus uruguayanus Ritter ex Kiesling, Darwiniana 24: 448-450, 1982

- Cereus peruvianus auct. non Miller: Herter (1930); Lombardo (1946; 1964).

(Fig. 6F).

Epiphytic category: HLA (tr). TT.

Distribution: AR, CA, CL, CO, MA, RI, RO, SA, SO, TA,

Habitat: moist hillside forests, psammophilous forests, riverside forests and xeric hillside forests.

Conservation status: not estimated, due to the small number of collections available.

Observations: the species is notably underrepresented in local collections due to the inherent difficulties associated with herborization. The data presented for this species were obtained from herbarium specimens and field observations.

Taxonomic comment: in the region there are different interpretations with regard to the name of this species. We follow the taxonomic criteria of Flora do Brasil 2020 (2019). However, IBODA (2019) interpret the species present in Uruguay as Cereus uruguayanus. Additionally, another name used for this taxon in the region is $C$. alacriportanus Pfeiff. (Bauer \& Waechter 2006), which has several interpretations (Leuenberger 2004; Hunt et al. 2006); therefore, it lacks a taxonomic consensus.
Voucher: Legrand 3223 (MVM).

\section{Lepismium Pfeiff.}

Lepismium aculeatum (F.A.C. Weber) Barthlott, Bradleya 5: 99.1987 $\equiv$ Rhipsalis aculeata F.A.C. Weber, Rev. Hort. 64: 428, 1892.

Epiphytic category: HLC.

Distribution: AR.

Habitat: open thorn forest.

Conservation status: EN. The species is not included as a priority for conservation in Uruguay by Marchesi et al. (2013), and is absent in national protected areas. Therefore, we consider it relevant to add L. aculeatum to the list of species considered as priority for conservation in Uruguay.

Observations: the species was collected only in one locality in Uruguay.

Voucher: Berazategui \& Duarte s.n. (MVM 21051).

Lepismium cruciforme (Vell.) Miq., Bull. Sci. Phys. Nat. Néerl. 1838: 49.1838 ERhipsalis cruciforme (Vell.) A. Cast., Anales Mus. Nac. Hist. Nat. Buenos Aires. Ser. 3 32: 496. 1925 ECactus cruciformis Vell., Fl. Flumin. 207. 1825 [1829].

= Rhipsalis myosurus (Salm-Dyck ex DC.) Foerster., Handb. Cact. 455, 1846.

Epiphytic category: HLC.

Distribution: AR, CL, RO, TT. Uruguay is the southern limit of distribution.

Habitat: riverside forests and moist hillside forests.

Conservation status: VU. The species is considered as a priority for conservation in Uruguay by Marchesi et al. (2013), and occurs in the protected area 'Paisaje Protegido Paso Centurión y Sierra de Ríos'.

Observations: the species is known from two areas in the country, one in northern Uruguay and the other in the east of the country.

Voucher: Del Puerto 2060 (MVFA).

Lepismium lumbricoides (Lem.) Barthlott, Bradleya 5: 99. 1987 इRhipsalis lumbricoides (Lem.) Lem. ex Salm-Dyck, Ill. Hort. 6: misc. 88. 1859 $\equiv$ Cereus lumbricoides Lem. Cact. Gen. Sp. Nov. 60. 1839.

(Fig. 5A).

Epiphytic category: HLC.

Distribution: AR, CL, CO, FA, MA, PA, RN, RI, RO, SA, SJ, SO, TA, TT.

Habitat: hydrophilous forests, open thorn forests, psammophilous forests, riverside forests, moist hillside forests and xeric hillside forests.

Conservation status: LC. 
Observations: it is the most widely distributed epiphytic cactus in Uruguay, present throughout the country.

Voucher: Berro 2144 (MVFA).

Rhipsalis Gaertn.

Rhipsalis cereuscula Haw., Philos. Mag. Ann. Chem. 7: 112.1830.

= Rhipsalis saglionis (Lem.) Otto, Repert. Bot. Syst. 2: 936. 1843.

(Fig. 5B).

Epiphytic category: HLC.

Distribution: AR, TA.

Habitat: riverside forests.

Conservation status: VU. The species is considered as a priority for conservation in Uruguay by Marchesi et al. (2013), and occurs in the protected area 'Área de Manejo de Hábitats y/o Especies Rincón de Franquía'.

Observations: most records are from northwestern Uruguay. However, two recent collections from Tacuarembó (Brussa \& Álvarez s.n. MVJB 30298, MVJB 30300), expand the distribution of this species to central Uruguay.

Voucher: Anonymus (Herb. Osten 17328, MVM).

Rhipsalis floccosa Salm-Dyck ex Pfeiff., Enum. Diagn. Cact. 134. 1837.

Epiphytic category: HLC.

Distribution: RI.

Habitat: moist hillside forests.

Conservation status: VU. The species is considered as a priority for conservation in Uruguay by Marchesi et al. (2013) and occurs in the protected area 'Paisaje protegido Valle del Lunarejo'.

Voucher: Bayce et al. s.n. (MVFA 17322).

\section{Commelinaceae}

\section{Tradescantia L.}

Tradescantia crassula Link \& Otto, Icon. Pl. Rar. 2: 13, pl. 7. 1828.

Epiphytic category: HLA (sx).

Distribution: CL, MA, RO, TT. Uruguay is the southern limit of distribution.

Habitat: moist hillside forests and xeric hillside forests.

Conservation status: NT.

Voucher: Mai \& Abreu s.n. (MVJB 29773).

Tradescantia fluminensis Vell., Fl. Flumin. 3:140, pl. 152. 1825.

= Tradescantia albiflora Kunth, Enum. Pl. 4: 84. 1843.
Epiphytic category: HLA (tr).

Distribution: AR, CA, CL, CO, FA, MA, MO, RI, RN, RO, SA, SO, TT.

Habitat: hydrophilous forest and riverside forest.

Conservation status: LC.

Voucher: Mai \& Rossado 189 (MVJB).

Tradescantia mundula Kunth, Enum. Pl. 4: 83. 1843. (Fig. 6I).

Epiphytic category: HLA (tr).

Distribution: CL, LA, RI, RO, TT.

Habitat: hydrophilous forests, moist hillside forests and riverside forests.

Conservation status: NT

Voucher: Rosengurtt \& Del Puerto s.n. (MVFA 10762).

Tradescantia tenella Kunth, Enum. Pl. 4: 83. 1843.

= Tradescantia anagallidea Seub., Fl. Bras. 3(1): 249. 1871.

Epiphytic category: HLA (tr).

Distribution: AR, CL, FA, LA, MA, RI, RO, SJ, SO, TA, TT.

Habitat: hydrophilous forests, moist hillside forests, open thorn forests, riverside forests and xeric hillside forests.

Conservation status: LC.

Voucher: Izaguirre et al. s.n. (MVFA 21083B).

\section{Moraceae}

Ficus L.

Ficus cestrifolia Schott, Syst. Veg. [Sprengel] editio decima sexta 4(App.): 409. 1827.

(Fig. 8 C;D).

Epiphytic category: HE.

Distribution: RO. Uruguay is the southern limit of distribution.

Habitat: moist hillside forest and psammophilous forest.

Conservation status: EN. The species is considered as a priority for conservation in Uruguay by Marchesi et al. (2013), but is absent in national protected areas.

Taxonomic comment: there is no present consensus regarding the names Ficus cestrifolia and F. organensis Miq. Some authors interpret the names as synonyms (Berg \& Villavicencio 2004; IBODA 2019), while others regard them as two different species (Pelissari \& Romaniuc Neto 2013; Romaniuc Neto et al. 2015). More work needs to be done to solve this taxonomic problem. For this publication, we use F. cestrifolia, because the Uruguayan specimens agree with the protologue and it is also the oldest name. 
Observations: the species is only represented by three collections in national herbaria, all from nearby localities in southeastern Uruguay.

Voucher: Brussa \& Gago s.n. (MVJB 28367).

Ficus luschnathiana (Miq.) Miq., Ann. Mus. Bot. Lugduno-Batavi. 3: 298. 1867 EUrostigma luschnathianum Miq. Fl. Bras. 4 (1): 101. 1853.

= Ficus monckii Hassl., Annuaire Conserv. Jard. Bot. Genève 21: 127. 1919.

= Ficus monckii Hassl. var. san-martinianus Parodi, Darwiniana 6: 165, f. 5, t. 10. 1943.

= Ficus diabolica Herter, Revista Sudamer. Bot. 6: 150, f. p. 152. 1940.

(Fig. 8A, B).

Epiphytic category: HE.

Distribution: AR, CL, CO, RN, RI, RO, SA, SO, TA, TT. Uruguay is the southern limit of distribution.

Habitat: riverside forest and xeric hillside forests.

Conservation status: LC.

Observations: the species is the most widely distributed hemiepiphytic species of the country, but it is scarcely represented in national herbaria.

Voucher: Lombardo 2454 (MVJB).

\section{Orchidaceae}

Acianthera Scheidw.

Acianthera hygrophila (Barb. Rodr.) Pridgeon \& M.W. Chase, Lindleyana 16(4): 244. 2001. EPleurothallis hygrophila Barb. Rodr., Gen. Sp. Orchid. 1: 7. 1877.

Epiphytic category: HLC.

Distribution: CL. Uruguay is the southern limit of distribution.

Habitat: riverside forests.

Conservation status: EN. The species was cited for Uruguay some years ago (Rossado et al. 2014) so, it is not included as a priority for conservation in Uruguay by Marchesi et al. (2013). As it was previously suggested in Rossado et al. (2014), we consider it relevant to add A. hygrophila to the list of species considered as a priority for conservation in Uruguay.

Observations: the species was collected only in one locality in Uruguay. The species occurs in the protected area 'Paisaje Protegido Paso Centurión y Sierra de Ríos'.

Voucher: Rossado et al. 178 (MVFA, MVJB).

Acianthera pubescens (Lindl.) Pridgeon \& M. W. Chase, Lindleyana 16(4): 245. 2001. झPleurothallis pubescens Lindl., Companion Bot. Mag. 2: 355. 1836.

= Pleurothallis riograndensis Barb. Rodr., Gen. Sp. Orchid. 2: 28.1882.
Epiphytic category: HLC.

Distribution: CL, RO. Uruguay is the southern limit of distribution.

Habitat: hydrophilous forests.

Conservation status: EN. The species is considered as a priority for conservation in Uruguay by Marchesi et al. (2013), but is absent in national protected areas.

Observations: the species shows a restricted distribution in eastern Uruguay.

Voucher: Brescia et al. s.n. (MVFA 16348).

Acianthera sonderiana (Rchb. f.) Pridgeon \& $\mathrm{M}$. W. Chase, Lindleyana 16(4): 246. 2001. 三 Pleurothallis sonderiana Rchb. f., Linnaea 22: 830. 1849 [1850].

(Fig. 5H).

Epiphytic category: HLC.

Distribution: CL. Uruguay is the southern limit of distribution.

Habitat: hydrophilous forests, moist hillside forests and riverside forests.

Conservation status: VU. The species is considered as a priority for conservation in Uruguay by Marchesi et al. (2013), and occurs in the protected area 'Paisaje Protegido Paso Centurión y Sierra de Ríos'.

Observations: the species shows a restricted distribution in the east of the country.

Voucher: Izaguirre et al. s.n. (MVFA 21093B).

\section{Campylocentrum Benth.}

Campylocentrum aromaticum Barb.Rodr., Contr. Jard. Bot. Rio de Janeiro 4: 103. 1907.

Epiphytic category: HLC.

Distribution: CL, TT. Uruguay is the southern limit of distribution.

Habitat: moist hillside forests and riverside forests.

Conservation status: VU. The species is considered as a priority for conservation in Uruguay by Marchesi et al. (2013), and occurs in the protected area 'Paisaje Protegido Paso Centurión y Sierra de Ríos'.

Voucher: Izaguirre et al. s.n. (MVFA 19156).

Capanemia Barb. Rodr.

Capanemia micromera Barb. Rodr., Gen. Sp. Orchid. 1: 138.1877.

(Fig. 5I).

Epiphytic category: HLC.

Distribution: CL, RI, RO, TA, TT. Uruguay is the southern limit of distribution.

Habitat: moist hillside forest and riverside forest.

Conservation status: LC. The species is considered as 
a priority for conservation in Uruguay by Marchesi et al. (2013). We consider that its presence in the country has been underestimated for a long time, due to the small size of the plants. In recent years, records for this species have increased considerably.

Voucher: Izaguirre et al. s.n. (MVFA 19099).

Capanemia superflua (Rchb. f.) Garay, Bot. Mus. Leafl. 21: 261. 1967. $\equiv$ Oncidium superfluum Rchb. f., Ann. Bot. Syst. 6: 721. 1861 .

Epiphytic category: HLC.

Distribution: CL, LA, MA. Uruguay is the southern limit of distribution.

Habitat: riverside forests.

Conservation status: EN. The species is considered as a priority for conservation in Uruguay by Marchesi et al. (2013), and occurs in the protected area 'Paisaje Protegido Paso Centurión y Sierra de Ríos'.

Observations: this species shows two distribution areas in eastern Uruguay, with few records in either one.

Voucher: Duarte \& Berazategui s.n. (MVM 21160).

\section{Cyclopogon C. Presl}

Cyclopogon elatus (Sw.) Schltr. Repert. Spec. Nov. Regni Veg. Beih. 6: 53. 1919. 三 Spiranthes elata (Sw.) Rich., De Orchid. Eur. 37. 1817. = Satyrium elatum Sw., Prodr. 119. 1788.

(Fig. 6E).

Epiphytic category: HLA (tr, sx).

Distribution: AR, CA, CL, FA, LA, MA, RN, RI, RO, SA, SJ, TA, TT.

Habitat: hydrophilous forests, moist hillside forests, psammophilous forests, riverside forests and xeric hillside forests.

Conservation status: LC.

Observations: the species possibly has a wider distribution in Uruguay, and it is underrepresented in the national herbaria.

Voucher: Del Puerto \& Marchesi 5267 (MVFA).

Gomesa R. Br.

Gomesa barbata (Lindl.) M.W. Chase \& N.H. Williams, Ann. Bot. (Oxford) 104(3): 395. 2009. EOncidium barbatum Lindl., Coll. Bot. t. 27. 1821.

Epiphytic category: HLC.

Distribution: CL. Uruguay is the southern limit of distribution.

Habitat: moist hillside forests.

Conservation status: EN. The species is considered as a priority for conservation in Uruguay by Marchesi et al. (2013) under the name Gomesa ciliata (Lindl.) M.W. Chase
\& N.H. William, and occurs in the protected area 'Paisaje Protegido Paso Centurión y Sierra de Ríos'.

Observations: the species shows a restricted distribution in the east of the country.

Voucher: Ziliani et al. s.n. (MVFA 20350).

Gomesa bifolia (Sims) M.W. Chase \& N.H. Williams, Ann. Bot. (Oxford) 104(3): 396. 2009. $\equiv$ Oncidium bifolium Sims, Bot. Mag. 36: t.1491. 1812.

(Fig. 5G).

Epiphytic category: HLC.

Distribution: AR, CL, CO, DU, LA, MA, PA, RN, RI, RO, SJ, SO, TA, TT.

Habitat: moist hillside forests, psammophilous forests, riverside forests and xeric hillside forests.

Conservation status: LC.

Observations: the species is the most frequent and widely distributed epiphytic orchid in Uruguay.

Voucher: Osten 2836 (MVM).

Gomesa uniflora (Booth ex Lindl.) M.W.Chase \& N.H.Williams, Ann. Bot. (Oxford) 104(3): 398. 2009. $\equiv$ Oncidium uniflorum Booth ex Lindl., Edwards's Bot. Reg. 29: t. 43.1843.

= Gomesa longipes (Lindl.) M.W. Chase \& N.H. Williams, Ann. Bot. (Oxford) 104(3): 397. 2009. 三 Oncidium longipes Lindl., Paxt. Fl. Gard. 1:46. 1850.

Epiphytic category: HLC.

Distribution: CL, TT. Uruguay is the southern limit of distribution.

Habitat: moist hillside forests and riverside forests.

Conservation status: EN. The species is considered as a priority for conservation in Uruguay by Marchesi et al. (2013), and occurs in the protected area 'Paisaje Protegido Paso Centurión y Sierra de Ríos'.

Voucher: Firpo s.n. (MVFA 33751).

\section{Hapalorchis Schltr.}

Hapalorchis lineatus (Lindl.) Schltr. Beih. Bot. Centralbl., Abt. 2. 37(2): 363. 1920. $\equiv$ Spiranthes lineata Lindl., Gen. Sp. Orchid. Pl. 471. 1840.

Epiphytic category: HLA (sx, tr).

Distribution: CA, CL, MA, RO. Uruguay is the southern limit of distribution.

Habitat: moist hillside forest, psammophilous forest and xeric hillside forest.

Conservation status: VU. The species is not included as a priority for conservation in Uruguay by Marchesi et al. (2013), and occurs in the protected area 'Paisaje Protegido Paso Centurión y Sierra de Ríos'.

Observations: due to its small size, possibly the species 
is underrepresented in national herbaria and could have a wider distribution in eastern and southeastern Uruguay.

Voucher: Rossado \& Pinelli 458 (MVFA).

Trichocentrum Poepp. \& Endl.

Trichocentrum pumilum (Lindl.) M.W. Chase \& N.H. Williams, Lindleyana 16(2): 138. 2001. EOncidium pumilum Lindl., Bot. Reg. 11: t. 920. 1825.

Epiphytic category: HLC.

Distribution: CL, RO, TT. Uruguay is the southern limit of distribution.

Habitat: moist hillside forests, psammophilous forests and riverside forests.

Conservation status: VU. The species is considered as a priority for conservation in Uruguay by Marchesi et al. (2013), but is absent in national protected areas.

Voucher: Berro 2858 (MVM).

\section{Piperaceae}

Peperomia Ruiz \& Pav.

Peperomia catharinae Miquel, Syst. Piperac. 127.1843. = Peperomia herteri Trelease, Rev. Sudamer. de Bot. 6: 66. 1941.

= Peperomia uruguayana Trelease, Rev. Sudamer. de Bot. 6: 66. 1941.

(Fig. 4G).

Epiphytic category: HLC.

Distribution: CL, LA, MA, RI, RO, TT. Uruguay is the southern limit of distribution.

Habitat: hydrophilous forests, riverside forests, moist hillside forests and xeric hillside forests.

Conservation status: LC.

Voucher: Arechavaleta 408 (MVM).

Peperomia comarapana C. DC., Meded. Rijks-Herb. 27: 8. 1915.

(Fig. 6C).

Epiphytic category: HLA (tr).

Distribution: AR, PA, RN.

Habitat: open thorn forests.

Conservation status: VU. The species is considered as a priority for conservation in Uruguay by Marchesi et al. (2013), but is absent in national protected areas.

Voucher: Berazategui et al. s.n. (MVM 23008).

Peperomia increscens Miquel, Linnaea 20: 124. 1847.

= Peperomia blanda var. pseudodindygulensis (C. DC.) Yunck., Lilloa 27: 218. 1953. 三Peperomia pseudodindygulensis C. DC., Mém. Soc. Phys. Genève 27(2): 307. 1882.
(Fig. 6D).

Epiphytic category: HLA (el, tr).

Distribution: AR, CL, PA, RI, RO, TA. Uruguay is the southern limit of distribution.

Habitat: moist hillside forests and xeric hillside forests.

Conservation status: NT

Observations: the species is distributed in eastern Uruguay, however a recent record from western Uruguay (Muñoz \& Diaz s.n. MVJB 30518), has extended considerably the distribution for this species in the country.

Voucher: Mai et al. 289 (MVJB).

Peperomia pereskiifolia (Jacq.) Kunth, Nov. Gen. Sp. (quarto ed.) 1: 68, [1815] 1816. ("pereskiaefolia") 三 Piper pereskiifolium Jacq., Collectanea 4: 126. 1790.

(Fig. 4H).

Epiphytic category: HLC.

Distribution: MA, RO. Uruguay is the southern limit of distribution.

Habitat: moist hillside forest, psammophilous forest

Conservation status: EN. The species is considered as a priority for conservation in Uruguay by Marchesi et al. (2013), but is absent in national protected areas.

Observations: the species has a restricted distribution in southeastern Uruguay and up to date has been only registered in three localities. Voucher: Alonso Paz 4680 (MVFQ).

Peperomia psilostachya C. DC., Mém. Soc. Phys. Genève 32 (2): 9, pl. 54, f. 6-9, 1893.

(Fig. 4F).

Epiphytic category: HLC.

Distribution: CL, RI. Uruguay is the southern limit of distribution.

Habitat: moist hillside forests and riverside forests.

Conservation status: EN. The species was cited for Uruguay few years ago (Mai et al. 2016) so, it is not included as a priority for conservation by Marchesi et al. (2013). Therefore, we consider it relevant to add P. psilostachya to the list of species considered as priority for conservation in Uruguay, as it was suggested in Mai et al. (2016). The species occurs in the protected area 'Paisaje Protegido Paso Centurión y Sierra de Ríos'.

Observations: there are only two records for this species in Uruguay.

Voucher: Mai et al. 205 (MVJB).

Peperomia tetraphylla Hooker \& Arnott, Bot. Beechey Voy. 97. 1832.

= Peperomia reflexa (L. f.) A. Dietrich, Sp. Pl. (ed. 6) 1: 180. 1831., nom. illeg. non Kunth (1815 [1816]: 70) $\equiv$ Piper reflexum Linnaeus f., Suppl. Pl. 91. 1781. 
= Peperomia berroi Trelease. Revista Sudamer. Bot. 6: 67. 1941.

= Peperomia tacuariana Trelease, Revista Sudamer. Bot. 6: 66. 1941.

= Peperomia americana (Miq.) Herter, Revista Sudamer. Bot. 10 (2): 46. 1952. EPeperomia reflexa (L. f.) A. Dietrich fo. americana Miq., Syst. Piperac. 173. 1843.

= Peperomia arechavaletae var. minor Herter in Marchesi, Boletín Facultad de Agronomía 104: 10. 1968. - Peperomia arechavaletae var. minor Herter, Revista Sudamer. Bot. 10 (2): 45. 1952., nom. inval.

(Fig. 4E).

Epiphytic category: HLC.

Distribution: CL, MA, RI, RO, TT. Uruguay is the southern limit of distribution in America.

Habitat: moist hillside forests, hydrophilous forests and riverside forests.

Conservation status: LC.

Voucher: Berro 1213 (MVFA).

Peperomia trineuroides Dahlst. Kongl. Svenska Vetensk. Acad. Handl. 33(2): 198, t. 8, f. 2. 1900.

= Peperomia arechavaletae C. DC, Notizbl. Königl. Bot. Gart. Berlin 6: 466. 1917.

- Peperomia arechavaletae var. minor auct. non Herter: Marchesi (1968, p.p.)

(Fig. 7G).

Epiphytic category: HLF (sx).

Distribution: CL, RI, RO, TA, TT. Uruguay is the southern limit of distribution.

Habitat: moist hillside forests.

Conservation status: NT.

Voucher: Berro 1915 (MVFA).

\section{Discussion}

The epiphytic flora of Uruguay corresponds to $3.04 \%$ of the total native flora of the country, whereas woody species represent $13 \%$ (Haretche et al. 2012), based on the 2400 confirmed native species (Marchesi et al. 2013). As epiphytes and woody species are intrinsically associated with forests, these are significant values, especially when considering that most of the territory is dominated by grasslands, and that native forests cover only $5.2 \%$ of total surface (MGAP 2018). Although restricted in space, the quite distinct and widely distributed Uruguayan forest types represent a great importance for the conservation of the epiphytic flora. The absence of exotic epiphytes in natural environments indicates a well-preserved condition of these communities.

The richest epiphytic families in Uruguay are Bromeliaceae, Polypodiaceae and Orchidaceae, which are all highly specialized for canopy life, and are also among the most diversified vascular families in the worldwide epiphytic flora (Benzing 1990; Zotz 2013a). Additionally, all the three families show several essential adaptations to survive in dry environments or with intermittent moisture availability (Benzing 1987; Gentry \& Dodson 1987). These conditions are typical for a subtropical country like Uruguay, where the summer months can be relatively dry due to increased evaporation rates, and the winter months can be cold (Castaño et al. 2011), especially for many vascular epiphytes. These limiting factors might also explain why some common tropical families, such as Araceae and Gesneriaceae, do not extend with epiphytic habit southward into Uruguay.

The richest epiphytic families in Uruguay also match overall those found in epiphytic communities of humid subtropical areas in northeastern Argentina (Cabral \& Salas 2008; Martín 2014), eastern Paraguay (Basualdo et al. 2005) and southern Brazil (Gonçalves \& Waechter 2003; Giongo \& Waechter 2004; Buzatto et al. 2008; Staudt et al. 2012; Perleberg et al. 2013; Matos et al. 2017; Ramos et al. 2019). However, in Uruguay Orchidaceae shows a lower contribution when compared with these studies, where it stands as the richest plant family. The lower orchid richness recorded in our study is in accordance with the strong north to south decrease of species and genera in eastern subtropical South America (Waechter 1998), extending from Paraná state (Brazil) to Buenos Aires province (Argentina). The same decreasing tendency was reported for epiphytic cacti (Bauer \& Waechter 2011) and ferns (Gonzatti et al. 2016; Machado et al. 2016), and might also be explained by the decrease in average precipitation and temperature, and the concomitant increase of water deficit and number of frost days south of $30^{\circ} \mathrm{S}$ (Barros et al. 2006).

Tillandsia stands out as the richest epiphytic genus in Uruguay, and furthermore represents an overwhelming amount of atmospheric against urn or tank bromeliads (in the rate 15:2). In moist tropical regions, this proportion is commonly inverse, i.e., there are more bromeliads with water-containing rosettes of the genera Aechmea or Vriesea (Fontoura et al. 2012; Ramos et al. 2019). The combination of a dense cover of water-absorbing trichomes, the waterretention in narrow and succulent leaves and the reflective surfaces of plants given by grayish tones, positions several Tillandsia-species among the most xerophytic epiphytes, allowing their occurrence in dry or enduring water-deficit environments (Benzing 1987; 1990). Additionally, this genus includes both shade-tolerant species that inhabit closed and humid forests (e.g. hydrophilous forests and moist hillside forests) as well as light-demanding species adapted to open environments (e.g. open thorn forests), resulting in a wider distribution in Uruguay. Characteristic holoepiphytes (HLC) are by far the most diversified lifeform in the Uruguayan epiphytic flora, as can be expected, because they also belong for the most part to the richest and well-adapted families occurring in epiphytic environments. 
The predominance of this category has been often reported for epiphytic communities in moist subtropical climates (Gonçalves \& Waechter 2003; Barbosa et al. 2015; Machado et al. 2016). Facultative holoepiphytes (HLF) represent a diverse taxonomic group, commonly varying according to the environmental characteristics, such as the abundance of rocky outcrops (walls or boulders) inside or adjacent to forests. Several facultative epiphytes eventually are more abundant and achieve bigger sizes on rocks than on trees (e.g.: Asplenium gastonis). Accidental holoepiphytes (HLA) occur under two quite distinct exposure conditions; one comprises those plants which are more abundant on the forest floor and can be found as epiphytes (e.g.: Tradescantia fluminensis, Asplenium ulbrichtii), or on shaded rocks inside the forest (e.g.: Peperomia increscens, Billbergia nutans); another group comprises those plants which typically occur on sun-exposed cliffs, and accidentally reach the nearby trees (e.g.: Tillandsia arequitae, T. uruguayensis, T. xiphioides). Accidental epiphytism is also favoured by phorophyte traits, such as more horizontal branches, presence of cavities in the trunks, and a thick fissured bark, as in Pouteria salicifolia (Spreng.) Radlk; the persistent leaf sheaths in palms such as Butia spp. also favors accidental epiphytes. Hemiepiphytes are the less diversified group in Uruguay, comprising only two species of Ficus (Moraceae). Ficus luschnathiana is widespread throughout the country and both young epiphytes and adult stranglers are commonly found in forests and on isolated trees. Ficus cestrifolia is otherwise restricted to a few localities in southeastern Uruguay, where the species grows both as a terrestrial and epiphytic plant.

Regarding the assessment of conservation status, almost half the epiphytic flora of Uruguay fits into some threatened category. All the species identified as Endangered occur in only a few sites and generally have small populations. In some cases, the habitats are severely fragmented (e.g. for Acianthera hygrophila, Tillandsia loliacea, T. recurvifolia) or are naturally restricted (e.g. for Niphidium crassifolium, Pecluma paradiseae, P. pectinatiformis, Peperomia psilostachya). The species circumscribed as Vulnerable generally have a wider geographical range, and usually with more than one distribution area within Uruguay; some of them have a low number of records (less than 10) or the records are concentrated in few localities. However, some of these cases could be a result of under-sampling, mainly because of smallsized plants which are easily overlooked (e.g. Didymoglossum hymenoides, Hapalorchis lineatus). Although more than half $(60 \%)$ of the threatened species (EN and VU) are included in national protected areas, the rest of them remain in an endangered situation. The risk of extinction is particularly critical for those species with restricted distribution, because they are much more threatened by habitat loss or degradation resulting from different anthropic activities.

The catalogue comprises several species which typically occur in rain forests and seasonal forests of the Atlantic and Paranean biogeographic provinces (sensu Cabrera \& Willink 1973). The Atlantic forest is often reported as one of the world's biodiversity hotspots (Galindo-Leal \& Câmara 2003), showing high richness and endemism rates of vascular epiphytes (Martinelli et al. 2008; Menini Neto et al. 2016; Freitas et al. 2016). Several epiphytic species of these northern tropical and subtropical biogeographic provinces extend southwards into Uruguay. The relatively wide systematic participation of the Uruguayan epiphytes evidences that their occurrence is present in different taxonomic groups, such as ferns (e.g. Campyloneurum, Niphidium, Pecluma, Pleopeltis, Psilotum, Serpocaulon, and Vittaria) and angiosperms (e.g.: Peperomia, Lepismium, Rhipsalis), where it is especially relevant in orchids (e.g.: Acianthera, Capanemia, Gomesa). Besides this more tropical forest epiphytic flora, Uruguay also contains species extending from the dry and open forests and woodlands of the Chaco and Espinal biogeographic provinces, occurring mostly in northern Argentina (Cabral \& Salas 2008; Martín 2014; Arnesi et al. 2018; IBODA 2019) and western Paraguay (IBODA 2019). These species occur exclusively in western Uruguay, and also belong to different families and genera (e.g.: Lepismium aculeatum, Peperomia comarapana, Tillandsia duratii, $T$. ixioides and T. recurvifolia).

Among vascular epiphytes it is interesting to note that around half $(52 \%)$ of the non-endemic species reach their southernmost distribution in Uruguay. This southern limit is remarkable to orchids ( 10 of 12 species), ferns ( 13 of 25 species), and to the genus Peperomia (six of seven species) and Ficus (all the species in the country). This distributional trait of epiphytes was previously reported for orchids (Waechter 1998; Rossado et al. 2014) and peperomias (Mai et al. 2016), and is furthermore shared with many terrestrial woody species (Grela \& Brussa 2003; 2005; Brussa \& Grela 2007; Delfino et al. 2011; Haretche et al. 2012; Brussa 2016). The epiphytic examples given above reinforce the transitional nature of the Uruguayan flora, despite a single biogeographic province (Pampean) is commonly assigned to the entire country. Actually, the Uruguayan territory covers a remarkable combination of floristic elements from Atlantic, Paranean and Chacoan forests, as reported in previous works (Chebataroff 1942; Alonso-Paz \& Bassagoda 2002; Brussa \& Grela 2007; Haretche et al. 2012).

In conclusion, we hope that this updated list of vascular epiphytes of Uruguay will encourage other botanists and ecologists to study the epiphytic flora in more focused approaches, especially in population, community, and conservation ecology. The scientific contributions in these fields are essential at a time when the fate of many species is at risk, largely due to the shifting land use that Uruguay is currently experiencing. Continued fieldwork, especially in the northern and western scarcely studied areas can both increase the floristic list given in this catalogue and additionally expand the distribution range of the already known species. 


\section{Acknowledgements}

The authors thank the herbaria visited, especially the MVJB staff, where the specimens were deposited. Special thanks are due to Federico Haretche, Carlos Brussa and Eduardo Marchesi for information about certain species, and for bringing specimens from field. To V. Valtierra, V. Piñeiro, M. Zabaleta and N. Caballero for their participation in fieldwork, and to the reviewers for their comments. This work was funded by CSIC-UdelaR. P.M.thanks ANII and A.R. thanks CAP for the granting of a Master thesis scholarship.

\section{References}

Alonso-Paz E, Bassagoda MJ. 2002. Aspectos fitogeográficos y diversidad biológica de las formaciones boscosas del Uruguay. Ciência \& Ambiente 24: 1-9.

Arnesi EA, Barberis I, Vesprini JL. 2018. Distribución de epífitas vasculares sobre cuatro especies arbóreas en un bosque xerofítico del Chaco Húmedo, Argentina. Ecología Austral 28: 480-495.

Bachman S, Moat J, Hill AW, Torre J, Scott B. 2011. Supporting Red List threat assessments with GeoCAT: geospatial conservation assessment tool. ZooKeys 150: 117-126.

Barbosa MD, Becker DFP, Cunha S, Droste A, Schmitt JL. 2015. Vascular epiphytes of the Atlantic Forest in the Sinos River basin, state of Rio Grande do Sul, Brazil: richness, floristic composition and community structure. Brazilian Journal of Biology 75: 25-35.

Barfuss MHJ, Till W, Leme EMC, et al. 2016. Taxonomic revision of Bromeliaceae subfam. Tillandsioideae based on a multi-locus DNA sequence phylogeny and morphology. Phytotaxa 279: 1-97.

Barros V, Grimm A, Robertson A, Núñez M. 2006. Caracterización del clima de la cuenca del Plata. REGA 3: 13-28.

Basualdo I, Soria N, Degen R, Ortiz M, Zardini E. 2005. Catálogo de la flora vascular de Tavai, Dpto. Caazapa, Paraguay. Rojasiana 1: 27-99.

Bauer D, Waechter JL. 2006. Sinopse taxonômica de Cactaceae epifíticas no Rio Grande do Sul, Brasil. Acta Botanica Brasilica 1: 225-239.

Bauer D, Waechter JL. 2011. Padrões geográficos de cactáceas epifíticas no Rio Grande do Sul, Brasil. Pesquisas 62: 239-251.

Benzing DH. 1987. Vascular epiphytism: taxonomic participation and adaptive diversity. Annals of the Missouri Botanical Garden 74: 183204.

Benzing DH. 1990. Vascular epiphytes General biology and related biota. Cambridge, Cambridge University Press.

Berazategui P, Duarte W, García M, Villagrán E. 2010. Lepismium aculeatum (F.A.C. Weber) Barthlott (Cactaceae): Primer registro para la flora de Uruguay. Comunicaciones Botánicas del Museo de Historia Natural 4: 1-8.

Berg CC, Villavicencio X. 2004. Taxonomic studies on Ficus (Moraceae) in the West Indies, extra Amazonian Brazil, and Bolivia. Ilicifolia 5: 1-177.

Brito AH, Llano L. 2008. Bromelias del Uruguay. Montevideo, Linardi y Risso.

Brussa CA. 2016. Piper gaudichaudianum Kunth (Piperaceae), primer registro para la flora del Uruguay. Agrociencia Uruguay 1: 1-6.

Brussa CA, Grela I. 2007. Flora Arbórea del Uruguay. Con énfasis en las especies de Rivera y Tacuarembó. Montevideo, COFUSA.

Buzatto CR, Maria B, Severo A, Waechter JL. 2008. Composição florística e distribuição ecológica de epífitos vasculares na Floresta Nacional de Passo Fundo, Rio Grande do Sul. Iheringia 63: 231-239.

Cabral EL, Salas RM. 2008. Epifitismo en el nordeste argentino: composición y estructura comunitaria. In: Basterra NI, Neiff JJ, Casco S. (eds.) Manual de biodiversidad de Chaco, Corrientes y Formosa. Corrientes, Eudene. p.197-217.

Cabrera AL, Willink A. 1973. Biogeografía de América Latina. Serie de Biología, Monografía N¹3. Washington, Secretaria General de la O.E.A.
Carneiro AM, Farias-Singer R, Ramos RA, Nilson AD. 2016. Cactos do Rio Grande do Sul. Porto Alegre, Fundação Zoobotânica do Rio Grande do Sul.

Castaño JP, Giménez A, Ceroni M, Furest J, Aunchayna R. 2011. Caracterización agroclimática del Uruguay; 1980-2009. Montevideo, Serie Técnica INIA 193.

Cervi AC, Borgo M. 2007. Epífitos vasculares no Parque Nacional do Iguaçu, Paraná (Brasil). Levantamento preliminar. Fontqueria 51: 415-422.

Chebataroff J. 1942. La vegetación del Uruguay y sus relaciones fitogeográficas con la del resto de la América del Sur. Revista del Instituto Panamericano de Geografía e Historia 2: 49-93.

Christenhusz MJM, Zhang X, Schneider H. 2011. A linear sequence of extant families and genera of lycophytes and ferns. Phytotaxa 19: 7-54.

Delfino L, Piñeiro V, Mai P, Mourelle D, Garay A, Guido A. 2011. Florística y fitosociología del bosque psamófilo en tres sectores de la costa de Uruguay, a lo largo del gradiente fluvio-marino. Iheringia 66: 175-88.

Eggli U, Marchesi E, Bonifacino JM, Nyffeler R. 2008. Taxonomy and distribution of epiphytic cacti in Uruguay-notes towards a Checklist of Cactaceae of Uruguay, Part 3. Haseltonia 14: 141-169.

Evans AM. 1969. Interspecific relationships in the Polypodium pectinatumplumula complex. Annals of the Missouri Botanical Garden 3: 193-293.

Flora do Brasil. 2020 under construction. 2019. Jardim Botânico do Rio de Janeiro. http://floradobrasil.jbrj.gov.br/. 4 Feb. 2019.

Flores-Palacios A, García-Franco JG. 2001. Sampling methods for vascular epiphytes: their effectiveness in recording species richness and frequency. Selbyana 22: 181-91.

Fontoura T, Scudeller VV, Costa AF. 2012. Floristics and environmental factors determining the geographic distribution of epiphytic bromeliads in the Brazilian Atlantic Rain Forest. Flora 207: 662-672.

Freitas L, Salino A, Neto LM, et al. 2016. A comprehensive checklist of vascular epiphytes of the Atlantic Forest reveals outstanding endemic rates. PhytoKeys 58: 65-79.

Galindo-Leal C, Câmara IG. 2003. The Atlantic Forest of South America: biodiversity status, threats, and outlook. Island Press, United States of America.

Ganem MA, Giudice GE, Luna ML. 2016. Asplenium L. In: Zuloaga FO, Belgrano MJ. (eds.) Flora vascular de la República Argentina. Vol 2. Lycofitas. Helechos. Gymnospermae. Buenos Aires, Instituto de Botánica Darwinion. p. 54-76.

GBIF - The Global Biodiversity Information Facility. 2018. GBIF Home Page. https://www.gbif.org/species/6. 02 Jul. 2018.

Gentry AH, Dodson CH. 1987. Diversity and biogeography of neotropical vascular epiphytes. Annals of the Missouri Botanical Garden 74: 205-33.

Giongo C, Waechter JL. 2004. Composição florística e estrutura comunitária de epífitos vasculares em uma floresta de galeria na Depressão Central do Rio Grande do Sul. Revista Brasileira de Botânica 27: 563-572.

Gonçalves CN, Waechter JL. 2003. Aspectos florísticos e ecológicos de epífitos vasculares sobre figueiras isoladas no norte da planície costeira do Rio Grande Do Sul. Acta Botanica Brasilica 17: 89-100.

Gonzatti F, Machado L, Windisch PG. 2016. Distribution patterns of ferns and lycophytes in the Coastal Region of the state of Rio Grande do Sul, Brazil. Acta Botanica Brasilica 2: 239-253.

Grela I, Brussa CA. 2003. Relevamiento florístico y análisis comparativo de comunidades arbóreas de Sierra de Ríos (Cerro Largo-Uruguay). Agrociencia 7: 11-26.

Grela I, Brussa CA. 2005. Novedades para la flora del Uruguay: nuevo registro de Agarista (Ericaceae). Acta Botanica Brasilica 3: 511-514.

Guerrero EL, Cellini JM. 2017. Corrimiento del límite austral en tres especies de Pleopeltis (Polypodiaceae) y su posible relación con el cambio climático en Buenos Aires, Argentina. Cuadernos de Investigación UNED 9: 51-58.

Haretche F, Mai P, Brazeiro A. 2012. Woody flora of Uruguay: inventory and implication within the Pampean Region. Acta Botanica Brasilica 26: 537-552.

Herter G. 1928. Las Plantas Uruguayas de Ernesto Gibert. Nomenclator Gibertianus. Estudios Botánicos en la Región Uruguaya. V. Montevideo, Imprenta Nacional.

Herter G. 1930. Flora Uruguayensis, Plantae Vasculares. Estudios Botánicos en la Región Uruguaya. IV. Montevideo, Imprenta Nacional. 
Herter G. 1939-1943. Flora Ilustrada del Uruguay I. Estudios Botánicos en la Región Uruguaya XIV. Montevideo/ Berlín/ Cracovia, Imprenta Nacional.

Herter G. 1940. Plantae uruguayenses novae vel criticae. Pars III. Revista Sudamericana de Botánica 6: 129-155.

Herter G. 1949. Flora del Uruguay. 1. Pteridophyta. Los Helechos. Estudios Botánicos en la Región Uruguaya. XXIV. Montevideo, Mimeografeado.

Hunt DR, Nigel PT, Charles G. 2006. The new cactus lexicon. International Cactaceae Systematics Group. Milborne Port, DH Publications.

IBODA - Instituto de Botánica Darwinion. 2019. Base de datos. Flora del Cono Sur. Buenos Aires, IBODA. http:// www2.darwin.edu.ar/. 4 Feb. 2019.

IUCN 2012. IUCN Red List Categories and Criteria: Version 3.1. 2nd. edn. Gland/ Switzerland/ Cambridge, IUCN.

Izaguirre P. 1972. El género Capanemia (Orchidaceae) en el Uruguay. Boletín de la Sociedad Argentina de Botánica 14: 225-231.

Izaguirre P. 1985. Las orquídeas silvestres del Uruguay. Almanaque del Banco de Seguros del Estado 68: 159-164.

Izaguirre P. 2013. Novedades en orquídeas para Uruguay: segunda contribución. Plantas epífitas. Agrociencia 17: 22-35.

Kersten RA. 2010. Epífitas vasculares - Histórico, participação taxonômica e aspectos relevantes, com ênfase na Mata Atlântica. Hoehnea 37: 9-38.

Kottek M, Grieser J, Beck C, Rudolf B, Rubel F. 2006. World map of the Köppen- Geiger climate classification updated. Meteorologische Zeitschrift 15: 259-263.

Kreft H, Köster N, Küper W, Nieder J, Barthlott W. 2004. Diversity and biogeography of vascular epiphytes in Western Amazonia, Yasuní, Ecuador. Journal of Biogeography 31: 1463-1476.

Legrand D, Lombardo A. 1958. Flora del Uruguay I. Pteridophyta. Montevideo, Museo Nacional de Historia Natural.

Lellinger DB. 1988. Some new species of Campyloneurum and a provisional key to the genus. American Fern Journal 78: 14-34.

Leuenberger BE. 2004. The Cactaceae of the Willdenow herbarium, and of Willdenow (1813). Willdenowia 34: 309-322.

Lombardo A. 1946. Flora arbórea y arborescente del Uruguay: con clave para determinar las especies. Montevideo, Laboratorios Galien.

Lombardo A. 1964. Flora arbórea y arborescente del Uruguay: con clave para determinar las especies. 2nd. edn. Montevideo, Laboratorios Galien.

Machado LS, Gonzatti F, Windisch PG. 2016. Epiphytic ferns in swamp forest remnants of the coastal plain of Southern Brazil: latitudinal effects on the plant community. Acta Botanica Brasilica 30: 644-657.

Madison M. 1977. Vascular epiphytes: their systematic occurrence and salient features. Selbyana 2: 1-13.

Mai P. 2014. Flora epífita vascular de Uruguay con énfasis en helechos (Polypodiofitas). MSc. Thesis, Pedeciba UdelaR, Montevideo.

Mai P, Rossado AJ, Bonifacino JM, Waechter JL. 2016. Taxonomic revision of Peperomia (Piperaceae) from Uruguay. Phytotaxa 2: 125-144.

Marchesi E. 1964. Dos helechos nuevos para la flora Uruguaya. Comunicaciones Botánicas del Museo de Historia Natural de Montevideo 4: 1-3.

Marchesi E. 1965. Plantas nuevas o poco conocidas de la flora Uruguaya I. Comunicaciones Botánicas del Museo de Historia Natural de Montevideo 4: 1-3.

Marchesi E. 1968. Las Piperáceas del Uruguay. Boletín de la Facultad de Agronomía, Universidad de la República 104: 1-13.

Marchesi E. 1979. Acerca de la presencia de Psilotum nudum en el Uruguay. Comunicaciones Botánicas del Museo de Historia Natural de Montevideo 4: 1-2.

Marchesi E, Alonso-Paz E, Delfino L, García M, Haretche F, Brussa C. 2013. Plantas vasculares. In: Soutullo A, Clavijo C, Martínez-Lanfranco JA. (eds.) Especies prioritarias para la conservación en Uruguay. Vertebrados, moluscos continentales y plantas vasculares. Montevideo, SNAP/DINAMA/MVOTMA y DICYT/MEC. p.27-71.

Márquez G, Giudice GE, Ponce M. 2006. Pteridofitas de la reserva "Valle del Arroyo Cuñá Pirú” (Misiones, Argentina). Darwiniana 1: 108-126.

Martín SG. 2014. Diversidad y distribución espacial de las epífitas vasculares en palmares del Nordeste Argentino. MSc Thesis, Universidad Nacional del Nordeste, Corrientes.
Martinelli G, Vieira CM, Gonzalez M, et al. 2008. Bromeliaceae da Mata Atlântica brasileira: lista de espécies, distribuição e conservação. Rodriguésia 59: 209-258.

Martínez OG, Assis FC, Torres EIM, Cacharani DA, Jaimez DG. 2016. El género Pecluma (Polypodiaceae) en Argentina. Darwiniana 4: 234-251.

Matos JZ, Farias-Singer R, Senna RM, Ramos RA, Carneiro AM. 2017. Epífitos vasculares do Refúgio de Vida Silvestre Banhado dos Pachecos. Revista Eletrônica Científica da UERGS 3: 798-806.

Menini Neto L, Furtado S, Zappi D, de Oliveira Filho A, Forzza R. 2016. Biogeography of epiphytic Angiosperms in the Brazilian Atlantic forest, a world biodiversity hotspot. Brazilian Journal of Botany 39: 261-273.

MGAP 2018. Actualización del Manual de manejo de bosque nativo en Uruguay. Montevideo, Tradinco S.A.

Mirbel CFB. 1815. Élemens de physiologie végétale et de botanique. 2nd. edn. Paris, Magimel.

Moffett MW. 2000. What's "Up"? A critical look at the basic terms of canopy biology. Biotropica 4: 569-596.

Osten C, Herter G. 1925. Plantae Uruguayenses I. Pteridophyta. Los helechos de la República Oriental del Uruguay. Anales del Museo Nacional de Montevideo 2: 327-407.

Pelissari G, Romaniuc Neto S. 2013. Ficus (Moraceae) da Serra da Mantiqueira, Brasil. Rodriguésia 64: 091-111.

Pellegrini MOO. 2018. Wandering throughout South America: Taxonomic revision of Tradescantia subg. Austrotradescantia (DR Hunt) M. Pell. (Commelinaceae). PhytoKeys 104: 1-97.

Perleberg TD, Garcia ÉN, Pitrez SR. 2013. Epífitos vasculares em área com floresta estacional semidecidual, Pelotas, Rio Grande do Sul, Brasil. Ciência e Natura 2: 65-73.

Pincheira-Ulbrich J. 2011. Patrones de diversidad de plantas trepadoras y epifitas vasculares en el bosque lluvioso valdiviano de Sudamérica: una síntesis entre los años 2000 y 2010. ФYTON 80: 9-18.

Puerto O. 1987. Vegetación del Uruguay. Montevideo, Facultad de Agronomía.

Ramos FN, Mortara SR, Monalisa-Francisco N, et al. 2019. Atlantic epiphytes: a data set of vascular and non-vascular epiphyte plants and lichens from the Atlantic Forest. Ecology: 100: 1-59.

Rogalski JM, Zanin E. 2003. Composição florística de epífitos vasculares no estreito de Augusto César, Floresta Estacional Decidual do Rio Uruguai, RS, Brasil. Revista Brasilera de Botanica 4: 551-556.

Romaniuc Neto S, Carauta JPP, Vianna Filho MDM, et al. 2015 Moraceae in Lista de Espécies da Flora do Brasil. Rio de Janeiro, Jardim Botânico do Rio de Janeiro. http://floradobrasil.jbrj.gov.br/jabot/floradobrasil/ FB10140

Rossado AJ. 2018. Revisión taxonómica del género Tillandsia L. (Bromeliaceae) para Uruguay. MSc Thesis, Pedeciba UdelaR, Montevideo.

Rossado AJ, Mai P, Bonifacino JM, Waechter JL. 2014. Acianthera hygrophila (Orchidaceae), nuevo registro para Uruguay. Bonplandia 23: 143-150.

Rossado AJ, Donadío S, Bonifacino JM. 2018a. Tillandsia uruguayensis (Tillandsioideae, Bromeliaceae), a new epilithic species from Uruguay. Phytotaxa 2: 133-142.

Rossado AJ, Donadío S, Berazategui P, Bonifacino JM. 2018b. Novedades del género Tillandsia (Bromeliaceae, Tillandsioideae) para Uruguay. Boletín de la Sociedad Argentina de Botánica 53: 641-651.

Rossado AJ, Donadío S, Bonifacino JM. 2019. Tillandsia bandensis (Bromeliaceae): its lectotypification and a new subspecies from Uruguay. Phytotaxa 405: 15-26.

San Martín J, Espinosa A, Zanetti S, Hauenstein E, Ojeda N, Arriagada C. 2008. Composición y estructura de la vegetación epífita vascular en un bosque primario de Olivillo (Aextoxicon punctatum R. et P.) en el sur de Chile. Ecología Austral 18: 1-11.

Schimper AFW. 1903. Plant geography upon a physiological basis. Oxford, Clarendon Press.

Smith AR, Pryer KM, Schuettpelz E, Korall P, Schneider H, Wolf PG. 2006. A classification for extant ferns. Taxon 3: 705-731.

Smith LB. 1933. Notas on the Bromeliaceae of Uruguay. Ostenia: 359-362. Smith LB. 1972. Flora del Uruguay IV. Bromeliaceae. Comunicaciones botánicas Museo Nacional de Historia Natural 4: 1-31. 
Smith LB, Downs RJ. 1977. Tillandsioideae (Bromeliaceae). In: Smith LB, Downs RJ. (eds.) Flora Neotropica Monograph. Vol. 14. New York, Hafner Press.

SPLink 2018. Centro de Referência em Informação Ambiental, CRIA Fundação de Amparo à Pesquisa do Estado de São Paulo. www.splink. cria.org.br. Jul. 2018.

Staudt MG, Lippert APU, Cunha S, Becker DFP, Marchioretto MS, Schmitt JL. 2012. Composição florística de epífitos vasculares do Parque Natural Municipal Tupancy, Arroio Do Sal, RS-Brasil. Pesquisas, Botânica 63: 177-188.

Stevens PF. 2017. Angiosperm Phylogeny Website. http://www.mobot. org/MOBOT/research/APweb/. Jul. 2017.

Thiers B. [continuously updated]. 2018. Index Herbariorum: A global directory of public herbaria and associated staff. New York, New York Botanical Garden's Virtual Herbarium. http://sweetgum.nybg. org/science/ih/. Feb. 2018.

Torres EM, Sota ER, Ferrucci MS. 2013. Sinopsis de los helechos y licofitos del Parque Nacional Mburucuyá (Corrientes, Argentina).
Claves de Especies. Boletín de la Sociedad Argentina de Botánica 1: $121-136$.

Trelease W. [1939] 1941. Piperaceae Uruguayenses. Revista Sudamericana de Botánica 6: 65-69.

Trelease W, Herter WG. 1952. Piperaceae Uruguayenses curae posteriors. Revista Sudamericana de Botánica 10: 43-47.

Vasques DT, Prado J. 2011. Campyloneurum C . Presl (Polypodiaceae) no Estado de São Paulo, Brasil. Hoehnea 2: 147-163.

Waechter JL. 1998. Epiphytic orchids in eastern subtropical South America. In: Britto CE. (ed.) Proceedings of the 15th World Orchid Conference. Rio de Janeiro, Naturalia. p. 332-341.

Zotz G. 2005. Vascular epiphytes in the temperate zones: a review. Plant Ecology 176: 173-183.

Zotz G. 2013a. The systematic distribution of vascular epiphytes - a critical update. Botanical Journal of the Linnean Society 171: 453-481.

Zotz G. 2013b. 'Hemiepiphyte': a confusing term and its history. Annals of Botany 111: 1015- 1020 